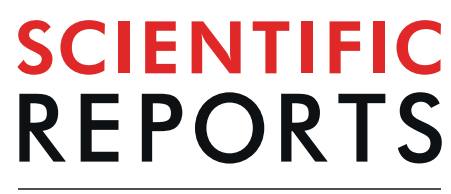

natureresearch

\title{
Cold atmospheric plasma generated reactive species aided inhibitory effects on human melanoma cells: an in vitro and in silico study
}

\author{
Dharmendra KumarYadav $\mathbb{D}^{1,3^{*}}$, Manish Adhikari ${ }^{2,3}$, Surendra Kumar ${ }^{1}$, Bhagirath Ghimire $\mathbb{D}^{2}$, \\ Ihn Han $\mathbb{D}^{2}$, Mi-Hyun Kim $\mathbb{D}^{1}$ \& Eun-Ha Choi ${ }^{2 *}$
}

Malignant melanoma is considered to be a heterogeneous disease that arises from altered genes and transformed melanocytes. In this study, special softjet cold atmospheric plasma was used to treat three different human melanoma cells using air and $\mathrm{N}_{2}$ gases to check the anti-melanoma activity. The physical effects by plasma revealed an increase in the temperature with the gradual reduction in $\mathrm{pH}$ at $60 \mathrm{sec}, 180 \mathrm{sec}$ and $300 \mathrm{sec}$ air and $\mathrm{N}_{2}$ plasma treatment. Cellular toxicity revealed a decreased in cell survival ( $-50 \%$ cell survival using air gas and $<\sim 60 \%$ cell survival using $\mathrm{N}_{2}$ gas at 60 sec plasma treatment in G-361 cells). Gene analysis by q-PCR revealed that $3 \mathrm{~min}$ and $5 \mathrm{~min}$ air and $\mathrm{N}_{2}$ plasma treatment activated apoptotic pathways by triggering apoptotic genes in all three melanoma cell lines. The apoptosis was confirmed by DAPI staining and its related pathways were further explored according to protein-protein docking, and their probable activation mechanism was revealed. The pathways highlighted that activation of apoptosis which leads to cellular cascades and hence stimulation ASK1 (docking method) revealed that softjet plasma can be an effective modality for human melanoma treatment.

Malignant melanoma considered as one type of cancer that primarily originates by a mutation in skin pigment making cells known as melanocytes ${ }^{1-5}$. Melanoma has the highest mortality rate worldwide and remains one of the most prominent types of skin cancer ${ }^{6}$. It is considered to be a heterogeneous disease with complex cellular mechanisms owing to specific genetic alterations that occur within several functionally related molecular pathways ${ }^{7}$. Methods for controlling cancer mostly depend on anticancer agents, which are limited and have after-effects. Thus, there must be an urgent need to adopt new technology for melanoma treatment. Soft jet cold atmospheric plasma (CAP) is a recent technological innovation that has opened a new research perspective to the melanoma treatment and other medical applications ${ }^{8}$, such as treating skin diseases ${ }^{9-11}$, dental problems ${ }^{12,13}$, and wounds ${ }^{14}$. The softjet plasma device uses high voltage and current to discharge plasma by using different gas or gaseous mixtures. The discharged CAP contains ionized gas molecules, electrons, excited atoms, ultraviolet (UV) radiations, electromagnetic fields, etc. The softjet plasma device induced reactive atoms to combine with each other and other molecules to form reactive oxygen and nitrogen species (RONS) ${ }^{15-17}$. These characteristics of soft jet cold atmospheric plasma have encouraged its therapeutic application for melanoma treatment.

Here, we examined the effect of soft jet CAP using air and $\mathrm{N}_{2}$ gases on normal human dermal fibroblast (nHDF) and different human melanoma cell lines: G-361, SK-MEL-31, and WM-266-4. CAP is nowadays proposed to be used in cancer treatment, but very few studies and evidence on the effect of softjet CAP on melanoma are available so far. The heating effect and increase in $\mathrm{pH}$ are the most common issues with traditional cold plasma technology and can be controlled with a softjet device.

${ }^{1}$ Gachon Institute of Pharmaceutical Science \& Department of Pharmacy, College of Pharmacy, Gachon University, Incheon, Republic of Korea. ${ }^{2}$ Plasma Bioscience Research Center, Applied Plasma Medicine Center, Department of Electrical \& Biological Physics, Kwangwoon University, Seoul, Republic of Korea. ${ }^{3}$ These authors contributed equally: Dharmendra KumarYadav and Manish Adhikari. *email: dharmendra30oct@gmail.com; ehchoi@kw.ac.kr 
The focus of this study was to estimate the anti-melanoma activity of softjet CAP by using air and $\mathrm{N}_{2}$ gases and an evaluation of the plausible mechanism to targeted melanoma treatment. We hypothesize that plasma exposure from different gases individually induces cancer cell death with minimal effects on normal adjacent cells. The results demonstrated the downregulation of metabolic viability with the simultaneous upregulation of apoptosis and its related genes. This new approach toward abrogating the apoptotic pathway using softjet CAP may provide a different strategy for melanoma treatment. We further explored the role of selected reactive oxygen and nitrogen species in modulating the apoptotic pathway through a protein-protein docking simulation. The in vitro results showed that soft jet CAP from the air and $\mathrm{N}_{2}$ gas can plausibly be used to inhibit melanoma progression.

\section{Materials and Methods}

RPMI-1640, MEM, phosphate-buffered saline, RIPA buffer and the penicillin-streptomycin antibody cocktail solution were obtained from Welgene, Korea. FBS and trypsin were procured from Hyclone (GE Healthcare Life Sciences), and the antibody cocktail used in this study (penicillin and streptomycin) was procured from Gibco, Korea. Nitric oxide and peroxide determination kit were procured from Bioassay Systems, USA. FGM-2, bulletkit was obtained from Lonza, NJ, USA. RNAiso plus (Trizol) was purchased from Takara, Japan. Glass bottom cell culture dishes were purchased from NEST, New Jersey, USA. Nitrocellulose membrane, Isopropanol and Triton X-100 were purchased from Thermofisher, Korea. Diethyl pyrocarbonate (DEPC) and 4\% Paraformaldehyde were obtained from Biosesang, Korea. The nucleus staining DAPI dye was procured from Sigma Aldrich, Korea. Anti-rabbit monoclonal cleaved caspase- 3 primary antibody was purchased from cell signalling technologies, USA and anti-mouse- GAPDH antibody was procured from Bio-Rad, USA. The ReverTra Ace ${ }^{\circledR}$ qPCR RT Master Mix cDNA synthesis kit was purchased from Toyobo, Japan. The SYBR Green Master mix was procured from Bio-Rad, Korea. All the primers for real-time polymerase chain reaction (q-PCR) analysis were obtained from Searchbio, Korea.

Device characterization. Electrical characteristics. The device used for the experimentation and its diagrammatic illustration was mentioned (Fig. 1a,b). The electrical characteristics (recorded with Lecroy wavesurfer 434, 350 MHZ oscilloscope using Tektronix P6015A high voltage probe and Tektronix P6022 current probe) for the soft plasma jet operated with air and nitrogen gas are shown in Fig. 1d,e. The flow rate of both gases was fixed at 1.5 liters per minute. Plasma was generated in dimming mode by using a DC to AC inverter whose operational time $\left(\mathrm{T}_{\text {on }}\right)$ and shutting time $\left(\mathrm{T}_{\text {off }}\right)$ were $13.71 \mathrm{~ms}$ and $114.80 \mathrm{~ms}$ (Fig. $\left.1 \mathrm{c}\right)$. The duty percentage was $\sim 11 \%$. A long shutting of time ( $\sim 90 \%$ of the total duty cycle) was essential in order to prevent heating of the plasma jet and enable longer operational duration. The current and voltage waveforms recorded during the Ton period of the circuit are shown in Fig. 1d,e for air and nitrogen gas respectively. For both air and nitrogen gas, the voltage waveforms appear distorted during each positive and negative half cycle of the applied voltage. The frequency of the source is $\sim 70 \mathrm{kHz}$. The dissipated power $(\mathrm{P})$ during the discharge was estimated by integrating the voltage $(\mathrm{V}(\mathrm{t}))$ and current $(\mathrm{I}(\mathrm{t}))$ signals recorded at each time points $(\mathrm{t})$ over one time period $(\mathrm{T})$ of the duty cycle as Kim et al. 2019,

$$
P=d u t y-\text { ratio } \times \int_{0}^{T} I(t) V(t) d t
$$

A comparison among the averaged values of applied voltage, total current, frequency and dissipated energy for the soft plasma jet operated with air and nitrogen gas are shown in Table 1. It can be seen that the values of breakdown voltage, total current and dissipated energy for the plasma jet operated with nitrogen gas are lower than that of (same) plasma jet operated with air gas.

Optical characteristics. The optical emission spectra (OES) of the discharge calibrated in the units of absolute irradiance $\left(\mu \mathrm{W} / \mathrm{cm}^{2} / \mathrm{nm}\right)$ recorded with HR4000 spectrometer (Ocean Optics Corporation) for plasma jet operated with air gas is shown in Fig. 1f. Emissions from various types of reactive oxygen and nitrogen species are clearly observed in the range of 200-900 $\mathrm{nm}$. Between $200-300 \mathrm{~nm}$, there are emissions from nitric oxide gamma $(\gamma)$ band at various wavelengths of $236 \mathrm{~nm}, 246 \mathrm{~nm}$, and $258 \mathrm{~nm}$. These species are originated through the interaction of electrons as well as metastable atoms with oxygen and nitrogen molecules which are present in the air $\operatorname{gas}^{18,19}$. An emission from hydroxyl radical $\left(\mathrm{OH}^{\bullet}\right)$ of a very short lifetime is observed from $306-309 \mathrm{~nm}$ due to the interaction of energetic electrons/metastable atoms with water molecules present in the feeding gas as well as the ambient environment. $\mathrm{OH}^{\bullet}$ radicals are strong precursors for the formation of long-lived reactive species like hydrogen peroxide $\left(\mathrm{H}_{2} \mathrm{O}_{2}\right)^{20}$. There are also strong emissions from nitrogen second positive system $\left(\mathrm{N}_{2} \mathrm{SPS}\right)$ from 315-380 nm and from nitrogen first negative system ( $\mathrm{N}_{2} \mathrm{FNS}$ ) from $390-440 \mathrm{~nm}^{18,19,21}$. Excited nitrogen molecules not only combine with ambient oxygen molecules to form secondary reactive species but also they are able to dissociate water molecules and lead to the formation of $\mathrm{OH}^{\bullet}$ radicals $^{22}$. In addition to these species, there are also emissions from atomic oxygen $(777 \mathrm{~nm}$ and $845 \mathrm{~nm})$ and atomic nitrogen $(747 \mathrm{~nm}$ and $868 \mathrm{~nm})$. The emission for plasma jet operated with nitrogen gas is quite similar to that of air gas but the emission from atomic oxygen is absent (Fig. 1g).

Temperature and pH estimation. MEM and RPMI cell culture serum-free media were placed in 48 well plates ( $1 \mathrm{ml}$ per well) and exposed to air and $\mathrm{N}_{2}$ gas plasma for $30 \mathrm{sec}, 60 \mathrm{sec}, 180 \mathrm{sec}$, and $300 \mathrm{sec}$. After the exposure time, the temperature and $\mathrm{pH}$ of the media were measured in triplicate with an infrared (IR) camera (Fluke Ti100 Series Thermal Imaging Cameras, UK) and a pH meter (Eutech Instruments, Singapore).

Cell lines for the study. The normal human dermal fibroblast (nHDF) and human melanoma cell lines (G-361, SK-MEL-31, and WM-266-4) were used to check the efficacy of air and $\mathrm{N}_{2}$ gas plasmas at different times and concentrations. All three melanoma cell lines were maintained in RPMI and MEM and supplemented with 


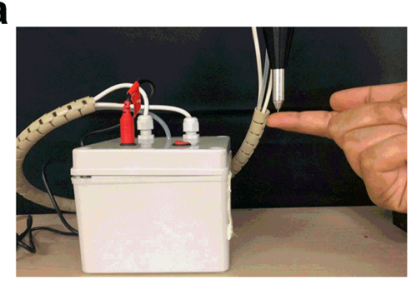

b

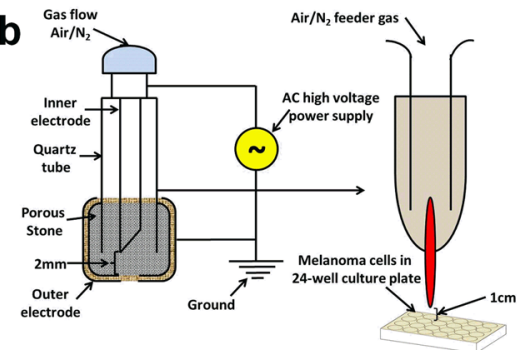

C

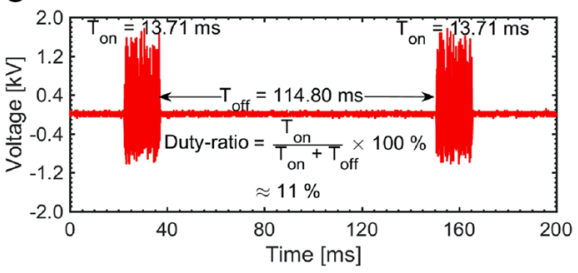

d

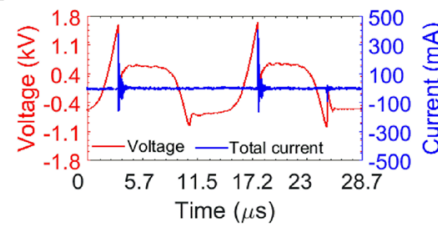

f

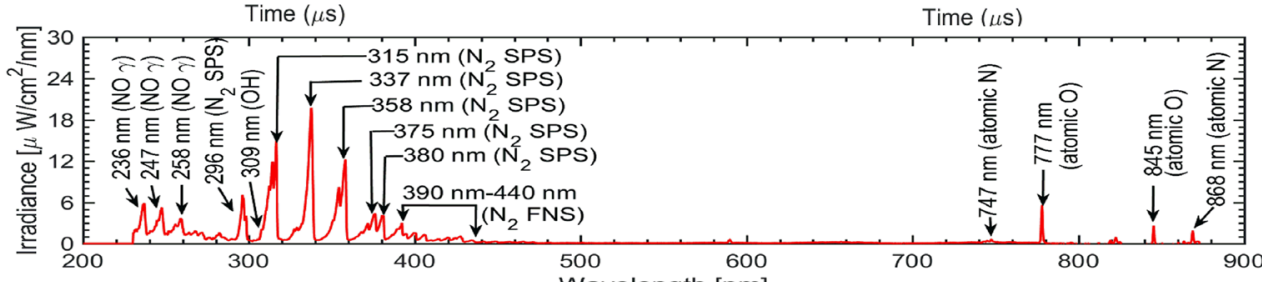

g

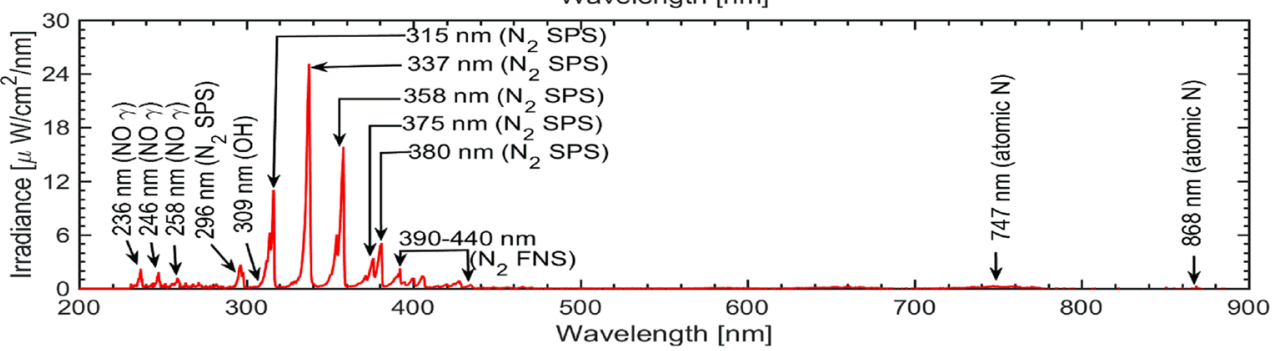

Figure 1. Illustration of softjet plasma jet device with different gas systems. (a) Device setup for the experiment; (b) Schematic representation of plasma jet on melanoma cells; (c) Waveforms showing the on-time and off-time of the plasma jet. Current-voltage waveforms of the discharge during plasma on time for plasma jet operated with (d) air gas (e) nitrogen gas; Optical characteristics of the plasma jet operated with (f) air gas; (g) nitrogen gas.

\begin{tabular}{|l|l|l|}
\hline Parameters & Air gas & Nitrogen gas \\
\hline Applied voltage $(\mathrm{kV})$ & 0.54 & 0.41 \\
\hline Total current $(\mathrm{mA})$ & 34.16 & 1.63 \\
\hline Frequency $\left(\mathrm{kHz} \_\right)$ & $\sim 70$ & $\sim 70$ \\
\hline Dissipated energy $(\mathrm{mJ} / \mathrm{s})$ & 24.20 & 3.11 \\
\hline
\end{tabular}

Table 1. A comparison of the values of major plasma parameters for the soft plasma jet operated with air and nitrogen gas.

(10-15\%) fetal bovine serum, $1 \%$ nonessential amino acids, $1 \%$ glutamine, $1 \%$ penicillin $(100 \mathrm{IU} / \mathrm{mL})$ and streptomycin $(100 \mathrm{mg} / \mathrm{mL})$ (Hyclone, USA) while nHDF cell line was maintain using FGM-2 bulletkit (Lonza, USA). All cultures were maintained at $37^{\circ} \mathrm{C}, 95 \%$ relative humidity, and $5 \% \mathrm{CO}_{2}$. The cells were grown in 24 -well plate until confluence for experimentation.

Alamar blue cytotoxicity assay. The cellular toxicity within all four cells was quantified with an Alamar Blue assay ${ }^{23}$, which is based on the enzymatic reduction of an indicator dye (resazurin to resorufin) by viable cells. Cells were seeded in 24 well plates for all experiments $(80,000$ cells $/ \mathrm{mL}$ for G-361 cells and 50,000 cells $/ \mathrm{mL}$ for nHDF, SK-MEL-31 and WM-266-4 cells). After $24 \mathrm{~h}$ of seeding, cells were given different doses of plasma from each gas. The distance between the nozzle of the jet plasma and upper surface of the cell culture media was kept at $1 \mathrm{~cm}$ throughout the experiments (Fig. 1b). The cells were incubated for $24 \mathrm{~h}$ after the plasma treatment. After $24 \mathrm{~h}$, all of the media were drained off and replaced with fresh media containing Alamar Blue (diluted 1:10) and kept for $4 \mathrm{~h}$ until the color changed from blue to pink to indicate cell viability. The absorbance at 570 and $600 \mathrm{~nm}$ 


\begin{tabular}{|c|c|}
\hline Name & Sequence $\left(5^{\prime}-3^{\prime}\right)$ \\
\hline 18 s rna F & CAGGTCTGTGATGCCCTTAGA \\
\hline 18 s rna $R$ & GCTTATGACCCGCACTTACTG \\
\hline$p 53 F$ & GCCССТCСТCAGCATCTTATC \\
\hline$p 53 R$ & AAAGCTGTTCCGTCCCAGTAG \\
\hline bax $F$ & AAGAAGCTGAGCGAGTGTCTC \\
\hline bax $R$ & GCTGGCAAAGTAGAAAAGGGC \\
\hline casp $8 F$ & CCCAAATCAACAAGAGCCTGC \\
\hline casp $8 R$ & TCAGACAGTATCCCCGAGGTT \\
\hline map $38 \mathrm{~F}$ & CAGTCAGGTTCAGGTTGTGCT \\
\hline $\operatorname{map} 38 R$ & GGGCTTCTTTGTTAGGGTTTG \\
\hline noxl $F$ & TCACССССТTTGCTTCTATCT \\
\hline $\operatorname{nox} 1 R$ & ATTCCTCCATCTCCTGTTCCA \\
\hline $\operatorname{nox} 2 F$ & TCAAGATGCGTGGAAACTACC \\
\hline $\operatorname{nox} 2 R$ & TTCAGATTGGTGGCGTTATTG \\
\hline $\operatorname{nox} 3 F$ & TATTGGCGTGTTCTTCTGTGG \\
\hline $\operatorname{nox} 3 R$ & TTCCTGGTGGAGTTCTTTGG \\
\hline $\operatorname{nox} 4 F$ & TCTGTTTGCTTGGGTTCATCT \\
\hline $\operatorname{nox} 4 R$ & AATCTCCTGGTTCTCCTGCTT \\
\hline nox $5 F$ & AGGCACCAGAAAAGAAAGCA \\
\hline $\operatorname{nox} 5 R$ & TCCATCTCCAGTTTAGTCAGCA \\
\hline
\end{tabular}

Table 2. Primer sequence used for the evaluation of mRNA sequence; F: forward primer; R: reverse primer.

was measured with a microplate reader (Biotek, Vermont, USA). The cell viabilities were assessed as the ratio between the absorbance of the plasma-treated and normal cells ${ }^{24,25}$.

Measurement of reactive species $\left(\mathrm{H}_{2} \mathrm{O}_{2}\right.$ and $\left.\mathrm{NO}_{x}\right)$ in cell culture media. The levels of peroxide $\left(\mathrm{H}_{2} \mathrm{O}_{2}\right)$ and different nitric oxide species $\left(\mathrm{NO}_{2}\right.$ and $\left.\mathrm{NO}_{3}\right)$ within the cell culture media (RPMI and MEM) were evaluated to compare the generation of reactive species after giving plasma treatment (air and $\mathrm{N}_{2}$ ). The reactive species were measured after $30 \mathrm{sec}, 60 \mathrm{sec}, 180 \mathrm{sec}$ and $300 \mathrm{sec}{ }^{26}$ plasma exposure and estimated in micromoles per liter $(\mu \mathrm{M})$ according to the manufacturer's protocol (BioAssay System, CA, USA). The absorbance was calculated at $585 \mathrm{~nm}$ for the $\mathrm{H}_{2} \mathrm{O}_{2}$ and $540 \mathrm{~nm}$ for the nitric oxides $\left(\mathrm{NO}_{\mathrm{x}}\right)$ radicals.

Apoptosis detection in human melanoma cells by DAPI staining and western blotting. All the three cells were cultured in their respective media overnight in glass bottom culture dish $35 \mathrm{~mm}^{2}$ (Nest, New Jersey, USA) before treatment with softjet plasma using air and $\mathrm{N}_{2}$ feeder gas. The cells were treated with $300 \mathrm{sec}$ air CAP and $300 \mathrm{sec} \mathrm{N}_{2} \mathrm{CAP}$ and kept it for $24 \mathrm{~h}$ in $\mathrm{CO}_{2}$ incubator. After incubation, the cells were fixed with $3.7 \%$ paraformaldehyde and washed $2 \mathrm{X}$ with sterile PBS. Afterwards, the cells were permeabilized with $0.5 \%$ Triton X-100 in PBS for $5 \mathrm{~min}$ and stained with DAPI $(1 \mathrm{mg} / \mathrm{ml})$ for $30 \mathrm{~min}$ at room temperature. The cells were again re-washed with PBS to avoid excessive staining and fluorescent images were captured and analysed using Olympus IX83-FP confocal microscope (Tokyo, Japan). For western blotting, cells were harvested after treated with CAP for $3 \mathrm{~min}$ and $5 \mathrm{~min}$ with air and $\mathrm{N}_{2}$ and then washed with PBS and lysed with RIPA buffer. Protein was quantified and separated on SDS-PAGE and transferred to nitrocellulose membrane. Primary antibodies for cleaved caspase 3 (anti-rabbit monoclonal, cell signaling Technology Inc., Danvers, MA, USA) and GAPDH (anti-mouse monoclonal, Bio-Rad, CA, USA) were incubated with membrane. The membrane was exposed with horseradish peroxidase (HRP)-conjugated secondary IgG antibodies.

Regulation of gene expression analysis using q-PCR in human melanoma cells. Any alteration in the cellular level must be associated with changes in gene expression at the mRNA level. To clarify in molecular levels, we identified some genes that responsible for the cellular apoptosis and degradation of cell membranes by the production of plasma generated reactive species. The primers of apoptotic genes ( $p 53$, bax, casp 8$)$, mitogen-activated protein kinase (map38), and different types of NADPH oxidase genes (nox 1-5) were designed and synthesized. All three melanoma cells were grown in 24 well plates and treated with softjet plasma using air and $\mathrm{N}_{2}$ gas separately. After incubation for $24 \mathrm{~h}$, the cells were trypsinized and collected for RNA isolation using Trizol (Invitrogen, USA), after which q-PCR was performed with a Biorad 2X SYBR green mix. Reactions were carried out in a Biorad thermal cycler (Biorad, Korea), and the results were expressed as the fold change calculated with the $\Delta \Delta \mathrm{C}_{\mathrm{t}}$ method relative to a control sample ${ }^{27}$. Meanwhile, $18 \mathrm{~s}$ rRNA was used as an internal normalization control. Quantitative real-time PCR was performed according to the forward and reverse primer sequences listed in Table 2 .

Computational modeling. The role of peroxide $\left(\mathrm{H}_{2} \mathrm{O}_{2}\right)$ and nitrogen $\left(\mathrm{NO}_{\mathrm{x}}\right)$ species in regulating the activity of the apoptotic pathway was determined by protein-protein docking and interaction analysis of apoptotic proteins: the apoptosis signal-regulating kinase 1 (ASK1) and thioredoxin 1 (TRX1) proteins. The human ASK1 protein has 1374 amino acids and consists of three domains: the N-terminal TRX-binding domain (ASK1-TBD), 


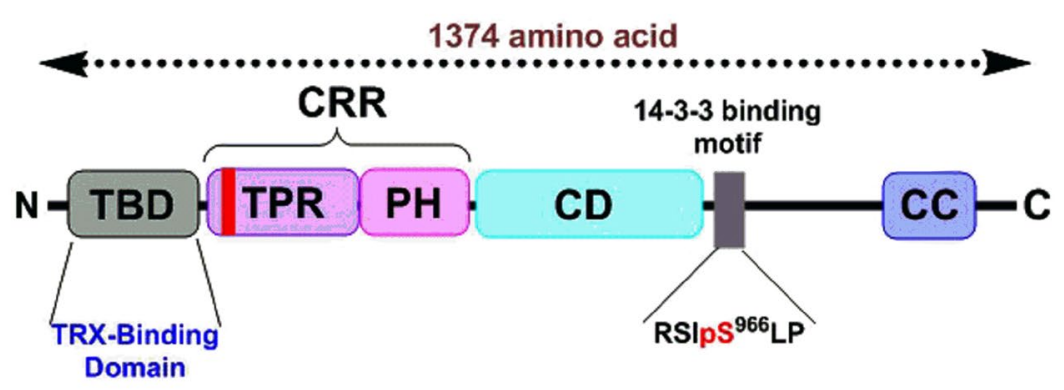

b
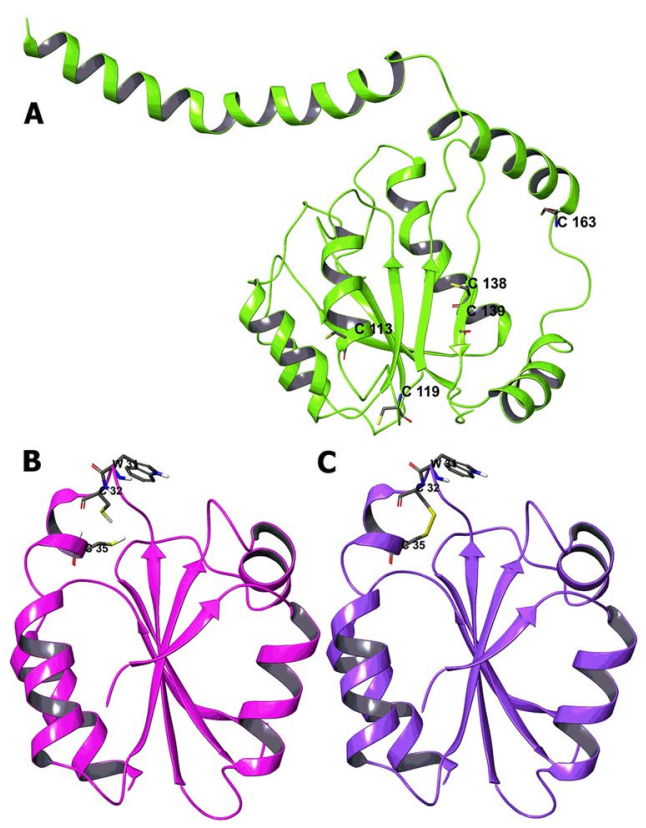

Figure 2. The schematic representation of the domain structure of ASK1. (a) TBD, TRX-binding domain; CRR, central regulatory region; TPR, tetratricopeptide repeats domain; PH, pleckstrin homology domain; CD, catalytic domain; CC, coiled-coil region. (b) (A) The ASK1-TBD (TRX-Binding domain) modeled protein with key amino acid residues, i.e., C98, C113, C119, C138, C139, and C163 (amino acid residues presented as single letter code); (B) The TRX-Reduced protein (PDB ID: 1ERT), and (C) The TRX-Oxidized protein (with key amino acid residues i.e. W31, C32, C35).

central regulatory region (ASK1-CRR) containing the TRAF-binding region, and serine/threonine kinase domain (ASK1-CD) located approximately in the center of the molecule ${ }^{28,29}$ (Fig. 2a).

Protein preparation. The three-dimensional structure of ASK1-TBD was still unknown and domain positioned between residues 46 and 277 in the N-terminal part of ASK1 (Fig. 2a). The homology model of ASK1-TBD was resolved by Obsil et al. ${ }^{29,30}$, whereas reduced TRX ${ }^{31}$ protein was obtained (PDB ID: 1ERT) in our study. To model the TRX (oxidized) caused by reactive oxygen and nitrogen species (RONS), an intramolecular disulfide bond was created between the Cys32 and Cys35 residues (Fig. 2b). These modeled protein structures were prepared according to the standard protocol: the addition of $\mathrm{H}$-atoms, optimization of the side chain and restrained minimization until a root-mean-square (RMS) gradient of $0.3 \AA$ is reached ${ }^{32}$.

Protein-protein interaction. For the protein-protein interaction analysis, the homology model ASK1 was used as the receptor and TRX1-reduced and TRX1-oxidised were used as the ligand. Docking was performed with the FRODOCK 2.0 program ${ }^{33,34}$, which identified the interaction-energy minima through a fast and exhaustive rotational docking search combined with translational scanning. The binding energy was approximated with four types of potentials: van der Waals, electrostatics, desolvation, and new coarse-grained knowledge-based protein docking. The program produced 1000 poses, and the cluster and absolute energy score were calculated. 
a

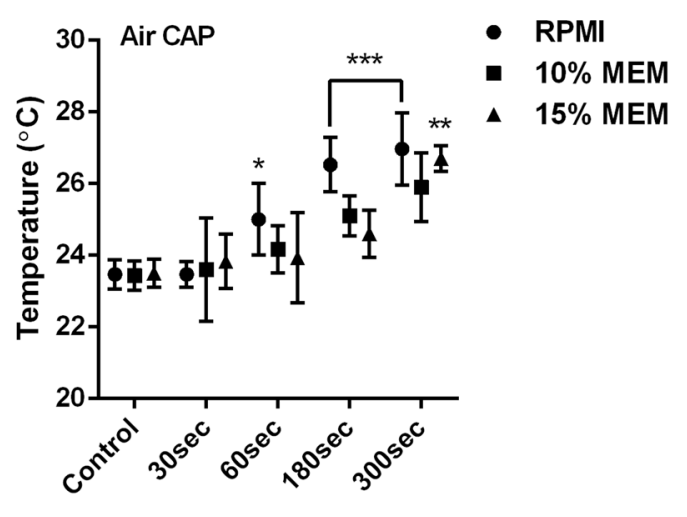

C

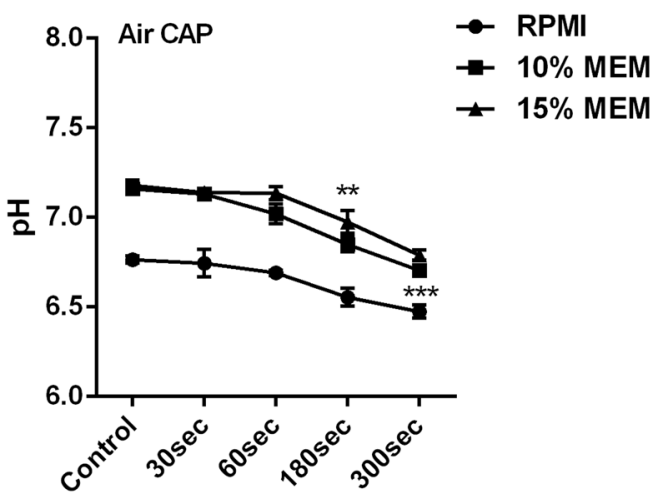

b

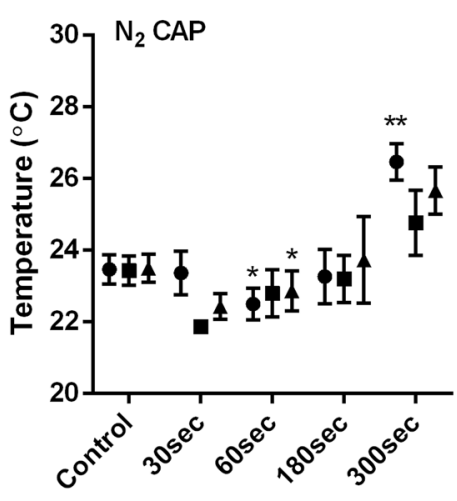

d

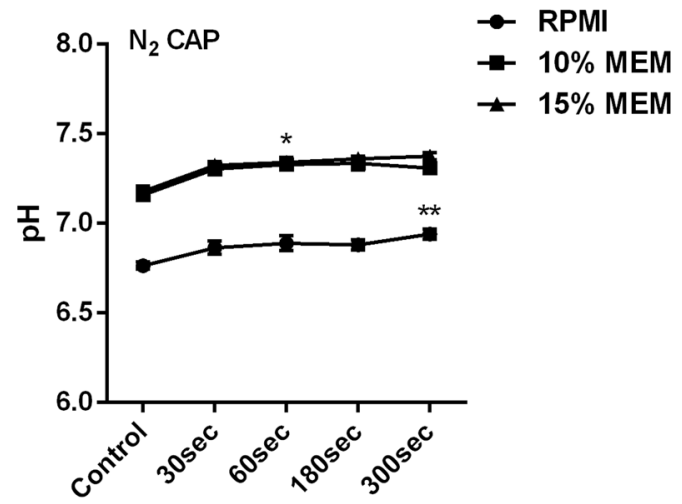

\ RPMI

- $10 \%$ MEM

- $15 \%$ MEM

Figure 3. Effect of temperature and $\mathrm{pH}$. (a,b) estimation of cell culture media temperature using air and $\mathrm{N}_{2}$ plasma and $(\mathbf{c}, \mathbf{d})$ estimation of $\mathrm{pH}$ using air and $\mathrm{N}_{2}$ plasma within cell culture media; after giving plasma treatment of $30 \mathrm{sec}, 60 \mathrm{sec}, 180 \mathrm{sec}$ and $300 \mathrm{sec}$. Student's t-tests were performed, and the levels of significance are indicated as follows: $* \mathrm{p}<0.05 ; * * \mathrm{p}<0.01$; and $* * * \mathrm{p}<0.001$

\section{Results}

Estimation of physical parameters ( $\mathrm{pH}$ and temperature). Previous studies using CAP with various jet plasma devices demonstrated that physical parameters within the solutions were changed, such as an increase in temperature ${ }^{26}$. However, softjet CAP device (PBRC, Seoul) was used in the present study was modified to overcome the heating effect which was common issues in previously used plasma devices. With air plasma, the temperature in cell media (RPMI, 10\% and 15\% MEM) showed an increase in temperature after $60 \mathrm{sec}, 180 \mathrm{sec}$, and $300 \mathrm{sec}$ treatment time (Fig. 3a). However, with $\mathrm{N}_{2}$ plasma, the temperature slightly dropped after $60 \mathrm{sec}$ treatment which later marginally increased and reached a maximum of up to $26.4^{\circ} \mathrm{C}$ in RPMI media after $300 \mathrm{sec}$ of treatment (Fig. 3b). This mainly attributed because of the softjet device built to minimize the heating effect at the treatment time.

The $\mathrm{pH}$ is dependent on primary free radicals generated by CAP and secondary free radicals produced by interaction with cell media and hence estimated for $30 \mathrm{sec}, 60 \mathrm{sec}, 180 \mathrm{sec}$, and $300 \mathrm{sec}$. Using air plasma, in the RPMI media, the measured pH slightly decreased after $30 \mathrm{sec}(6.64)$ which declined further to $180 \mathrm{~s}(6.55)$ and $300 \mathrm{~s}$ (6.47) as compared to control (6.7). The MEM media (10\% and 15\%) showed slightly decreased in pH after $30 \mathrm{sec}$, however, $60 \mathrm{sec}, 180 \mathrm{sec}$, and $300 \mathrm{sec}$ showed noticeable pH decreased. MEM 10\% decreased pH 7.02, 6.85, and 6.7 while, for $15 \% \mathrm{MEM}$, the $\mathrm{pH}$ also decreased in a time-dependent manner but was higher at $60 \mathrm{sec}(7.13)$, $180 \mathrm{sec}$ (6.97), and $300 \mathrm{sec}$ (6.79) (Fig. 3c).

However, $\mathrm{N}_{2}$ plasma exhibited a contrasting effect on the three different cell media compared to air plasma. Overall, it showed a slightly increased in $\mathrm{pH}$ at $30 \mathrm{sec}$ treatment which was remained constant at later treatment time (Fig. 3d).

Effect of air and $\mathrm{N}_{2}$ CAP on $\mathrm{H}_{2} \mathrm{O}_{2}$ and $\mathrm{NO}_{x}$ levels within cell media. With feeder gases, softjet CAP can generate a different kind of free radicals, ions, and UV rays that reacts with the liquid cell culture medium to form secondary reactive stable species like $\mathrm{H}_{2} \mathrm{O}_{2}, \mathrm{NO}_{2}$, and $\mathrm{NO}_{3}$, etc. Using air CAP the level of $\mathrm{H}_{2} \mathrm{O}_{2}$ within both cell media (RPMI and MEM) increased significantly at all treatment times as compared to the control. The softjet air CAP for $60 \mathrm{sec}$ induced $\mathrm{H}_{2} \mathrm{O}_{2}$ generation $(\sim 25 \mu \mathrm{M})$ within the RPMI media, which increased at $180 \mathrm{sec}$ $(40 \mu \mathrm{M})$ and $300 \mathrm{sec}(42 \mu \mathrm{M})$ of treatment. The MEM media showed comparable $\mathrm{H}_{2} \mathrm{O}_{2}$ levels at $30 \mathrm{sec}$ and $60 \mathrm{sec}$ treatment while it was higher after $300 \mathrm{sec}(46 \mu \mathrm{M})$ of treatment (Fig. $4 \mathrm{a})$ as compared to RPMI media. With $\mathrm{N}_{2}$ plasma the $\mathrm{H}_{2} \mathrm{O}_{2}$ level in the RPMI and MEM media slightly increased at $30 \mathrm{sec}$ and $60 \mathrm{sec}$ treatment. However, 
a

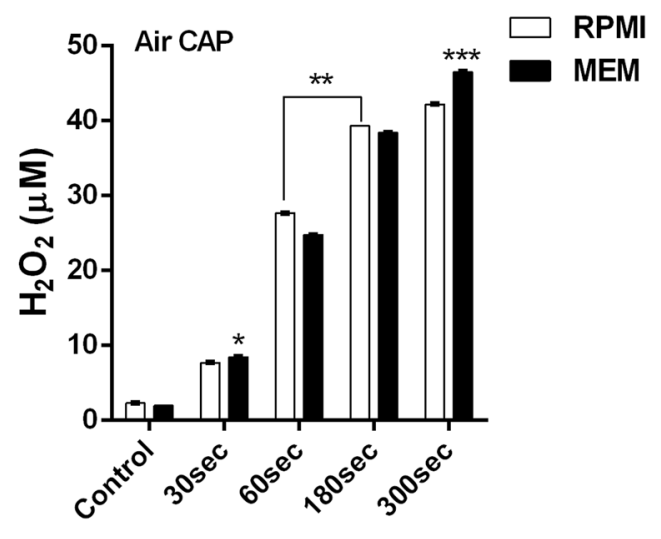

C

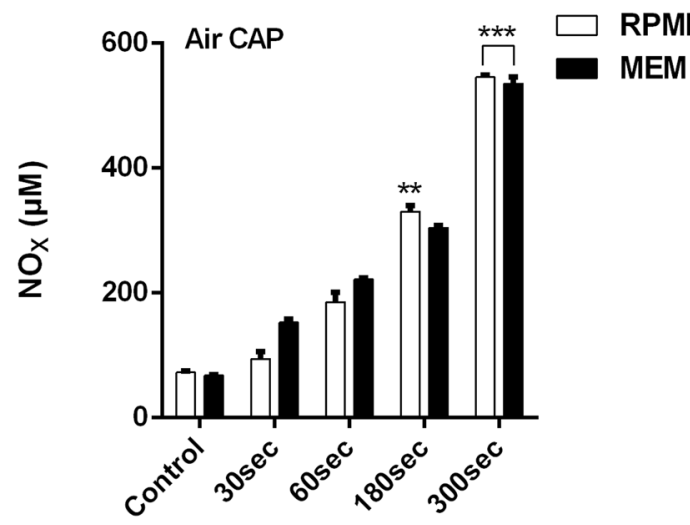

b
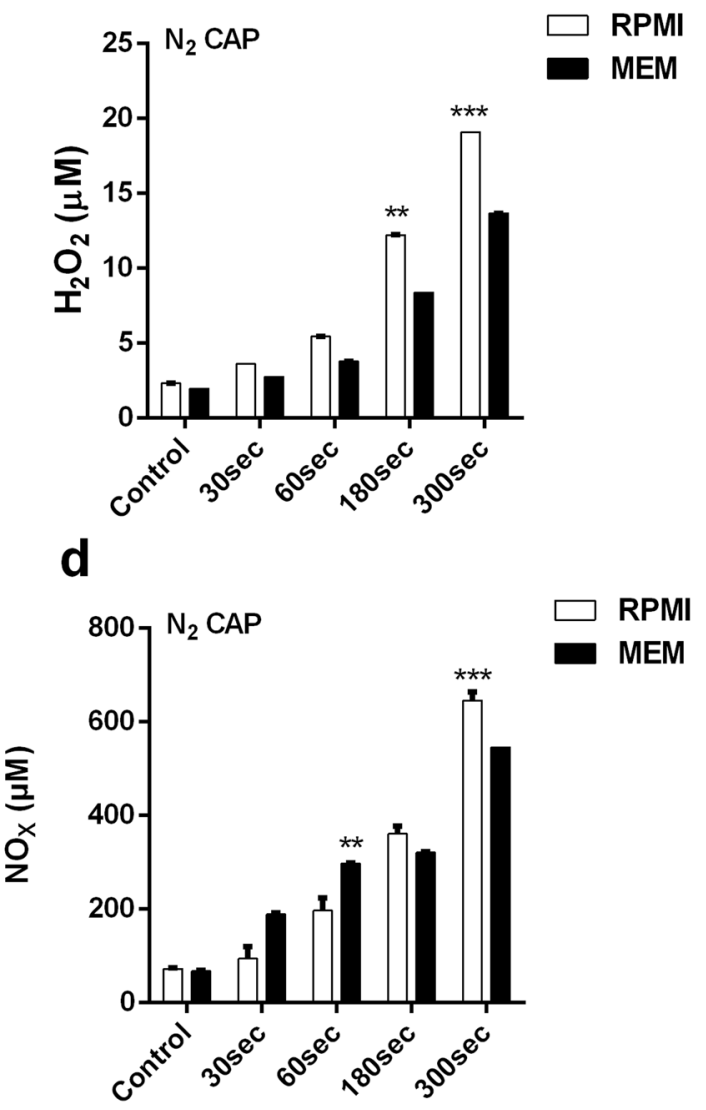

Figure 4. Free radical after giving softjet plasma treatment within cell media. (a,b) $\mathrm{H}_{2} \mathrm{O}_{2}$ level estimation using air and $\mathrm{N}_{2}$ cold plasma; (c,d) nitric oxide level estimation using air and $\mathrm{N}_{2}$ cold plasma. Student's t-tests were performed, and the levels of significance are indicated as follows: $* \mathrm{p}<0.05 ; * * \mathrm{p}<0.01$; and $* * * \mathrm{p}<0.001$.

$\mathrm{H}_{2} \mathrm{O}_{2}$ level alleviates significantly at $180 \mathrm{sec}(12 \mu \mathrm{M})$ which reaches a maximum at $300 \mathrm{sec}(20 \mu \mathrm{M})$ treatment for RPMI media. In contrast, the MEM media also exhibit an increase in the $\mathrm{H}_{2} \mathrm{O}_{2}$ level at $180 \mathrm{sec}(7 \mu \mathrm{M})$ and $300 \mathrm{sec}$ $(14 \mu \mathrm{M})$ respectively (Fig. $4 \mathrm{~b})$.

The level of $\mathrm{NO}_{\mathrm{x}}\left(\mathrm{NO}_{2}\right.$ and $\left.\mathrm{NO}_{3}\right)$ radicals within $\mathrm{RPMI}$ cell media, increased after air plasma treatment at all-time intervals, but MEM showed a higher NO concentration $(152.9 \mu \mathrm{M})$ than RPMI $(94 \mu \mathrm{M})$ after 30 sec and $60 \mathrm{sec}$ of treatment and reached its maximum at $300 \mathrm{sec}(545 \mu \mathrm{M})$ (Fig. 4c).

$\mathrm{N}_{2}$ plasma revealed more intense $\mathrm{NO}_{\mathrm{x}}$ production than the air plasma in both cell culture media. The $\mathrm{NO}_{\mathrm{x}}$ concentration increased significantly $(\mathrm{p}<0.001)$ in the RPMI media after $30 \mathrm{sec}$ treatment compared to the control and it revealed $60 \mathrm{sec}(197 \mu \mathrm{M}), 180 \mathrm{sec}(361 \mu \mathrm{M})$, and $300 \mathrm{sec}(646 \mu \mathrm{M}) \mathrm{NO}_{\mathrm{x}}$ species. However, MEM media showed a higher $\mathrm{NO}_{\mathrm{x}}$ concentration with $\mathrm{N}_{2}$ plasma treatment at $30 \sec (188 \mu \mathrm{M})$ and $60 \sec (298 \mu \mathrm{M})$ compared to the RPMI media at the same time intervals. Though, $\mathrm{NO}_{\mathrm{x}}$ concentration increased only slightly at $180 \mathrm{sec}$ (321 $\mu \mathrm{M})$ and reached a maximum at $300 \sec (545 \mu \mathrm{M})$ (Fig. $4 \mathrm{~d})$.

Estimation of CAP-induced toxicity. Cellular toxicity induced by softjet air and $\mathrm{N}_{2}$ CAP in three human melanoma cell lines (G-361, SK-MEL-31, and WM-266-4) were estimated using Alamar Blue ${ }^{\mathrm{Tm}}$ cytotoxicity assay at $10 \mathrm{sec}, 30 \mathrm{sec}, 60 \mathrm{sec}, 180 \mathrm{sec}$, and $300 \mathrm{sec}$. G-361 cells showed proliferation at $10 \mathrm{sec}$ treatment at all-time intervals. The cytotoxicity increased at $180 \mathrm{sec}$ of air CAP treatment (70\% survival) and remained the same after $300 \mathrm{sec}$ treatment when incubating for $24 \mathrm{~h}$. G-361 cells showed higher toxicity when receiving air and $\mathrm{N}_{2}$ CAP for $180 \mathrm{sec}$ and $300 \mathrm{sec}$ when incubating for $48 \mathrm{~h}$ and $72 \mathrm{~h}$. CAP treatment using air for $60 \mathrm{sec}$ declined survival rate (58\%), which increased further after $180 \mathrm{sec}\left(18 \%\right.$ survival) and $300 \mathrm{sec}$ ( $7 \%$ survival) of treatment (Fig. 5a). $\mathrm{N}_{2}$ CAP also showed similar trend like air CAP. The cytotoxic effect was higher after $60 \mathrm{sec}$ at $72 \mathrm{~h}$ incubation $(45 \%$ toxicity) and reached a minimum $\%$ survival at $300 \mathrm{sec}$ at all time-intervals (Fig. 5b). For SK-MEL-31, softjet air CAP didn't show much cytotoxicity at $10 \mathrm{sec}$ and $30 \mathrm{sec}$ treatment time at $24 \mathrm{~h}$ and $48 \mathrm{~h}$. However, SK-MEL-31 showed much higher cytotoxicity (60\%) when incubated for $48 \mathrm{~h}$ and $72 \mathrm{~h}$ at $180 \mathrm{sec}$ and $300 \mathrm{sec}$. The $\mathrm{N}_{2}$ CAP also showed similar effects like air CAP (Fig. 5c) after giving $10 \mathrm{sec}$ and $30 \mathrm{sec}$ treatments. However, at $60 \mathrm{sec}$ treatment time, the \% survival declined at all three time-intervals. At $180 \mathrm{sec}$ treatment, the cytotoxicity level increased significantly $(\mathrm{p}<0.001)$ as compared to control and remained constant at $300 \mathrm{sec}$ treatment time (Fig. 5d). Softjet air plasma treatment on WM-266-4 initially showed very low toxicity as compared to control and comparable. 

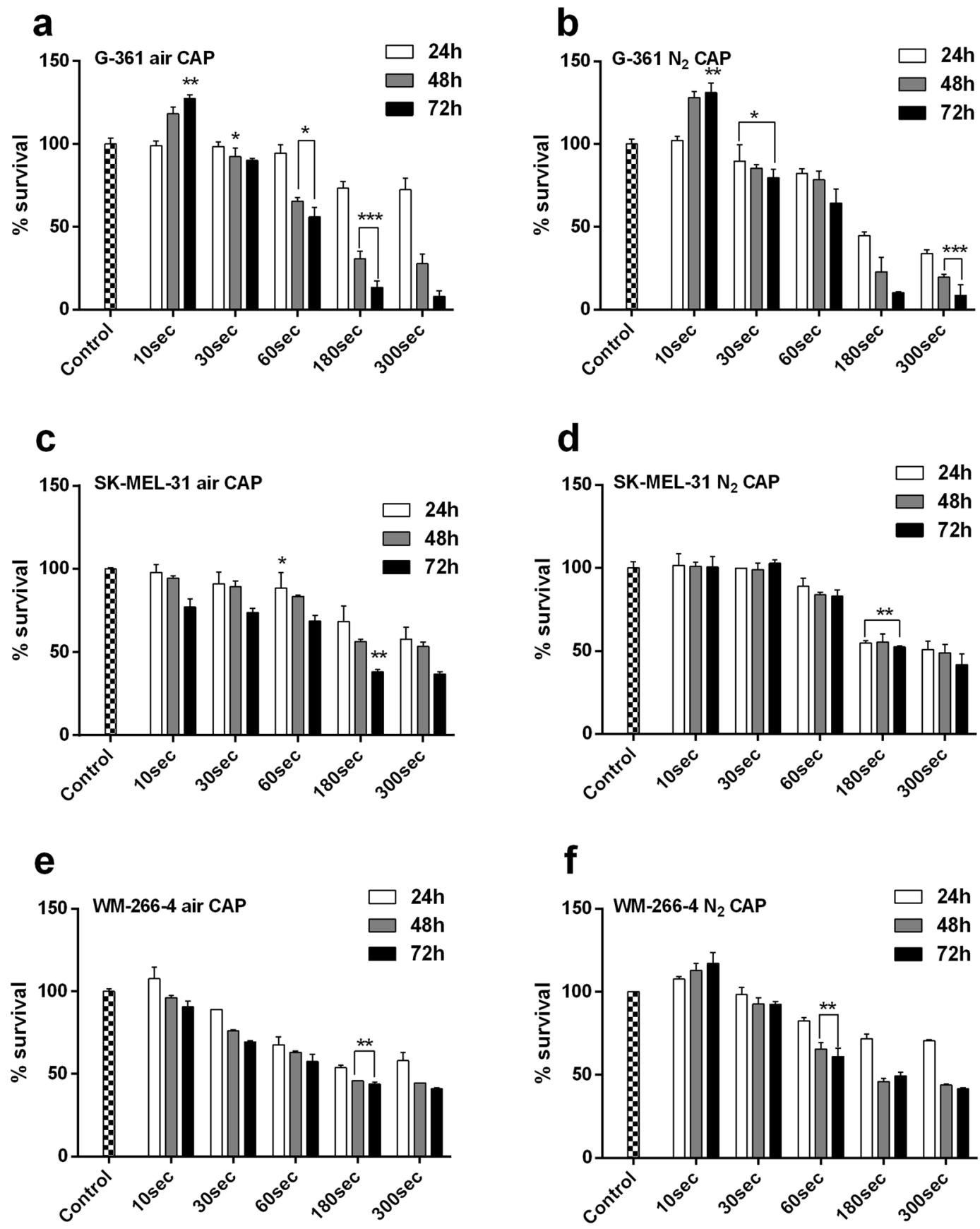

Figure 5. Assessment of $\%$ survival within different human melanoma cell lines at different plasma doses of $10 \mathrm{sec}, 60 \mathrm{sec}, 180 \mathrm{sec}$ and $300 \mathrm{sec}$ using softjet plasma (air and $\mathrm{N}_{2}$ gas) at $24 \mathrm{~h}, 48 \mathrm{~h}$, and $72 \mathrm{~h}$ incubation timeintervals. (a,b) G-361 human melanoma cells; (c,d) SK-MEL-31 human melanoma cells and (e,f) WM-266-4 human melanoma cells. Student's t-tests were performed, and the levels of significance are indicated as follows: $* \mathrm{p}<0.05 ; * \mathrm{p}<0.01 ;$ and $* * * \mathrm{p}<0.001$.

Though \% survival at $180 \mathrm{sec}$ CAP treatment, cytotoxicity was much higher and it remains the same at $300 \mathrm{sec}$ (Fig. 5e) which keeps on decreasing at all CAP doses and at all time-intervals.

For WM-266-4, N 2 CAP treatment decrease \% survival with 60 sec CAP treatment and continued to decrease with longer CAP treatment times up to $300 \mathrm{sec}$ for $48 \mathrm{~h}$ and $72 \mathrm{~h}$ incubation periods (Fig. 5f). However, nHDF cells showed non-significant effects while receiving air and $\mathrm{N}_{2}$ plasma jet at all time-intervals (Fig. S1). The microscopic data by differential interference contrast (DIC) images revealed that air CAP reduces the number of cells with higher pace as compared to $\mathrm{N}_{2}$ CAP after receiving CAP for $300 \mathrm{sec}$ (Fig. S2). Based on the data from the soft jet plasma using air and $\mathrm{N}_{2}$ for the three melanoma cell lines, we received $\mathrm{IC}_{50}$ of all three cell lines at $180 \mathrm{sec}$ ( $3 \mathrm{~min})$ and $300 \mathrm{sec}(5 \mathrm{~min})$ and hence kept these plasma doses constant for the study. 


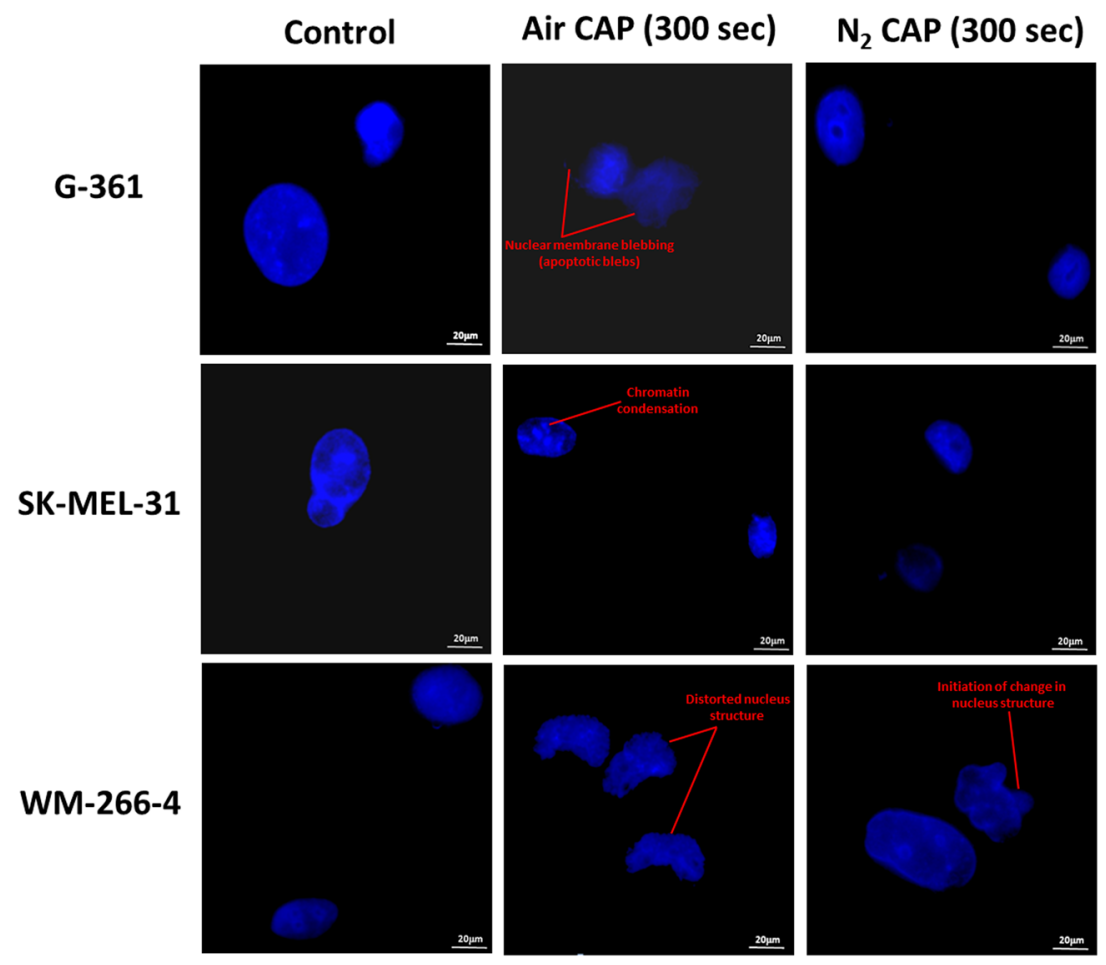

Figure 6. Detection of apoptosis by DAPI staining nuclei of G-361, SK-MEL-31 and WM-266-4 melanoma cells treated by using air and $\mathrm{N}_{2}$ CAP at $300 \mathrm{sec}$. (Magnification $=100 \mathrm{X}$ ).

Apoptosis detection by DAPI staining, western blotting and estimation of apoptotic and oxidative stress-related genes by air and $\mathrm{N}_{2}$ CAP treatment. The result outcome by individual treatment of $300 \mathrm{sec}$ Air CAP significantly provoked apoptosis as compared to $300 \mathrm{sec} \mathrm{N}_{2}$ CAP treatment. The induction of apoptosis was evident by DAPI staining using 100X magnification (Olympus IX83-FP confocal microscope, Tokyo, Japan) from the initial changes in the structure of nucleus (shrinkage) alonwith the occurrence of apoptotic bodies, nuclear membrane blebbing and chromatin condensation and fragmentation ${ }^{35}$ as shown in Fig. 6 .

However, $300 \sec \mathrm{N}_{2}$ CAP didn't affect much on nucleus structure except some initial changes in nuclear membrane, while control group shows prominent round shaped nucleus in all 3 human melanoma cell lines.

The present study illustrated that ROS induction after treatment with air and $\mathrm{N}_{2}$ CAP increased the levels of intracellular ROS that may be mediated through nox-1 and p53/atm gene expression levels. The generation of ROS by nicotinamide adenine dinucleotide phosphate-oxidase (nox) in response to apoptosis-related signaling is essential for signal transduction ${ }^{36,37}$. atm belongs to one of the largest protein kinase families and is responsible for regulating cellular responses and activating $\mathrm{H}_{2} \mathrm{AX}$ and $p 53$ in the DNA damage signaling cascade ${ }^{38}$. G-361 cells showed an increase of all apoptotic genes and nox 2, 4, 5 genes by A3 plasma treatment (Fig. 7f-h). The level of map 38 and atm genes increased up to 40 folds (Fig. 7a,b) while $p 53$ increased 14 folds (Fig. 7c) as compared to control. The level of cas 8 and bax also increased 20 folds after A3 treatment (Fig. 7d,e). While at A5 treatments all the apoptotic genes decreased significantly as compared to $\mathrm{A} 3$ and comparable to the control group.

N3 treatment in G-361 cells has no effects on map38, atm, p53, and bax but cas8 was increased (Fig. 7a-e). All apoptotic genes were increased at $\mathrm{N} 5$ treatment results in an increase in apoptotic genes. The nox 1 and 3 gene expressions were not detected for the G-361 cell line, while nox 2 and nox 4 increased after A3 and N3 treatments.

SK-MEL-31 melanoma cells revealed an increase in $p 53$, cas8, and bax levels after CAP treatment for A3, A5, and N3. The expression of apoptotic genes after $\mathrm{N}_{2}$ CAP treatment $\mathrm{N} 3$ significantly increased in all groups (Fig. 8). nox 1, 2, and 4 were not detected in the SK-MEL-31 cell line. However, an increased level of nox 3 was only detected N3 CAP treatment (3-fold), and the other treatments only showed insignificant increases (Fig. 8f). An increased level of nox 5 was detected after A3 (3-fold) and A5 (2.5-fold) treatment, while the level of nox 5 decreased after $\mathrm{N}_{2}$ CAP treatment for N5 (4.5-fold) compared to N3 (7-fold) respectively (Fig. 8g).

WM-266-4 melanoma cells showed an increase in all apoptotic genes after treating with air plasma (A3 and A5). Gene expression for map 38 (10-folds), atm (15-folds), p53 (8-folds), cas 8 (14-folds) and bax (15-folds) was increased after receiving $\mathrm{A} 3$ and comparable to $p 53$, cas 8 and bax after receiving A5 (Fig. 9a-e).

$\mathrm{N}_{2}$ CAP treatment (N3) increased some apoptotic gene expressions level. It increased map38 (18-folds), atm (18-folds), cas 8 (17-folds) and bax (40-folds) expression respectively compared to the control cells. N5 treatment didn't show much changes in the expression level of map38 and atm gene and compared to control. N5 treatment also increased the level of $p 53$ (3-folds), cas 8 (2-times) and bax (8-times) (Fig. 9a-e). nox3 gene was only expressed in A5 group while nox 5 gene expression was increased in A3 and A5 (Fig. 9f,g).

Using western blot analysis we accessed the stimulation of caspase 3 using both air and nitrogen CAP treatment on SK-MEL-31 and WM-266-4 human melanoma cell lines. cas3 activation was found in both of treatment 


\section{G-361}

a

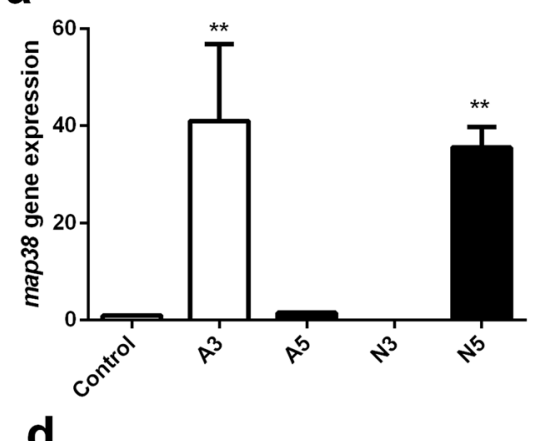

d

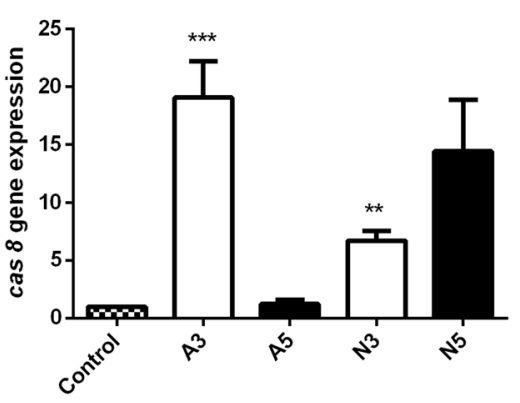

b

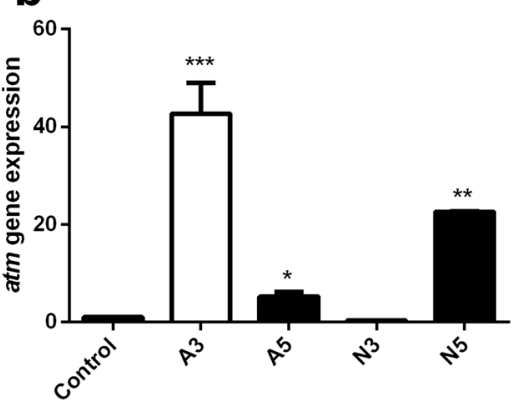

e

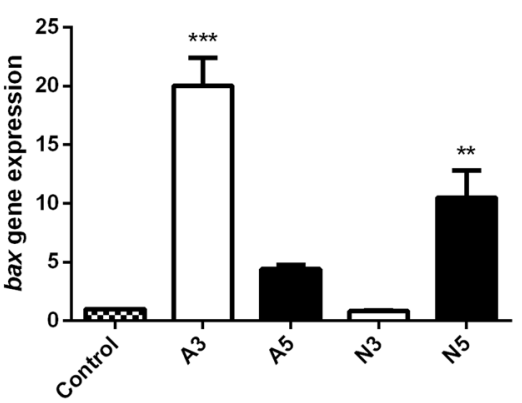

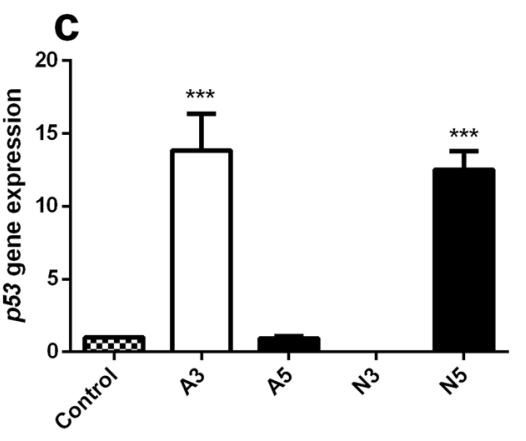

$f$

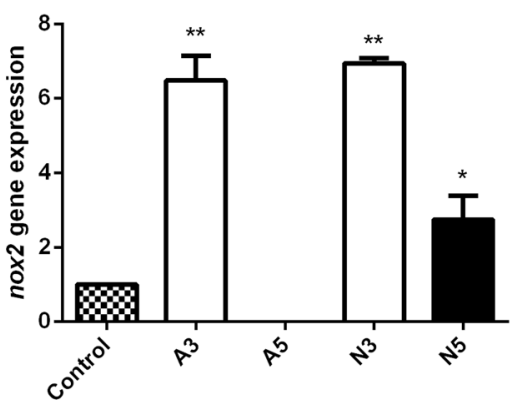

g

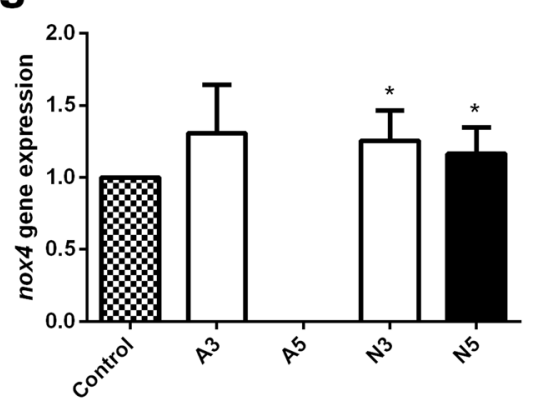

h

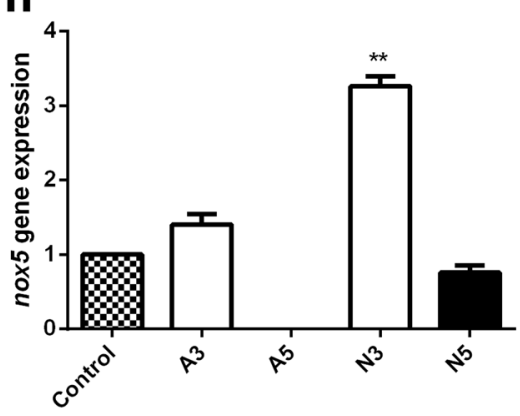

Figure 7. The relative value of mRNA expression of apoptosis and oxidative stress-related genes in G-361 human melanoma cells after plasma exposure for $180 \mathrm{sec}(\mathrm{A} 3 / \mathrm{N} 3)$ and $300 \mathrm{sec}$ (A5/N5) with air and $\mathrm{N}_{2}$ cold plasma. The relative mRNA expression of map38, atm, $p 53$, cas 8 , bax and nox (1-5) subfamily were measured by real-time RT-PCR and $18 s$ rRNA was used as a reference gene. Student's t-tests were performed, and the levels of significance are indicated as follows: $* \mathrm{p}<0.05 ; * \mathrm{p}<0.01$; and $* * * \mathrm{p}<0.001$.

group used with air and nitrogen gas and it shown the cas 3 expression significantly increased in 5 min air CAP as compared to $\mathrm{N}_{2}$ CAP. It indicate parallel result with q-PCR gene expression especially with cas 8 expression (Fig. S4).

\section{Discussion}

The poor diagnosis of metastatic melanoma despite conventional therapies has led to the development of new therapeutic strategies that not only treat the disease but also minimize the post-treatment effects ${ }^{39}$. Advances in model systems that closely simulate the human situation are much needed ${ }^{40}$. In the present study, we used a softjet CAP device with air and $\mathrm{N}_{2}$ feeder gases to analyze the inhibition rate in three human melanoma cell lines at different time intervals. The results revealed that the softjet CAP induced high cell death in the G-361, SK-MEL-31, and WM-266-4 human melanoma cells.

The physical characterization of softjet plasma devices by using both gases (air and $\mathrm{N}_{2}$ ) revealed the production of highly reactive radicals. CAP originating using the ambient air contained radicals mainly from $\mathrm{N}_{2}$ and $\mathrm{O}_{2}$ (e.g., $\mathrm{N}, \mathrm{O}, \mathrm{O}_{3}, \mathrm{NO}, \mathrm{NO}_{2}, \mathrm{OH}^{\bullet}$ ), while the CAP using $\mathrm{N}_{2}$ gas contained radicals of only unstable nitrogen species. The final products of these unstable species that reacted with the cell culture media results in the production of $\mathrm{H}_{2} \mathrm{O}_{2}$ and $\mathrm{NO}_{\mathrm{x}}$, which are quite stable. Even though it is still unclear which component of the softjet plasma induces toxicity. Therefore, we presume that this dose-dependent toxicity has the same tendency as the amounts of dissolved $\mathrm{H}_{2} \mathrm{O}_{2}$ and $\mathrm{NO}_{\mathrm{x}}$ in solution in published reports ${ }^{41}$. G-361 and SK-MEL-31 exhibited maximum cytotoxicity with $180 \mathrm{sec}$ of air CAP treatment after $48 \mathrm{~h}$ and $72 \mathrm{~h}$ of incubation, respectively. This may 
a
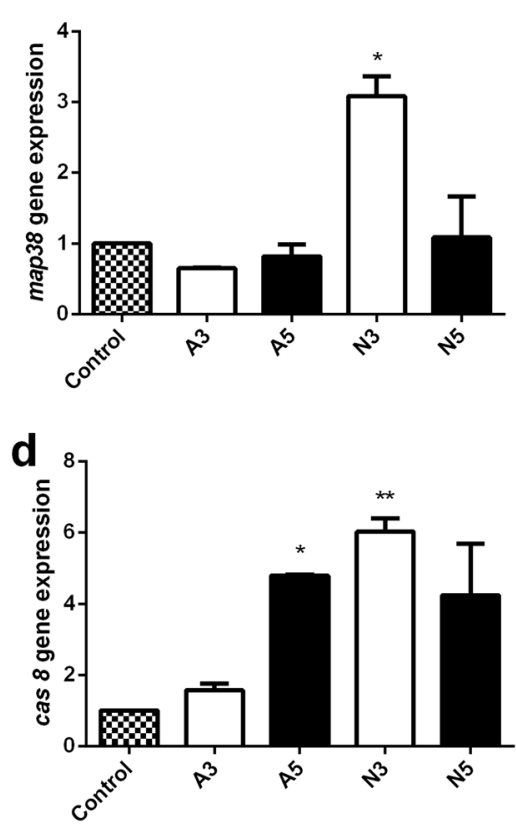

SK-MEL-31

b
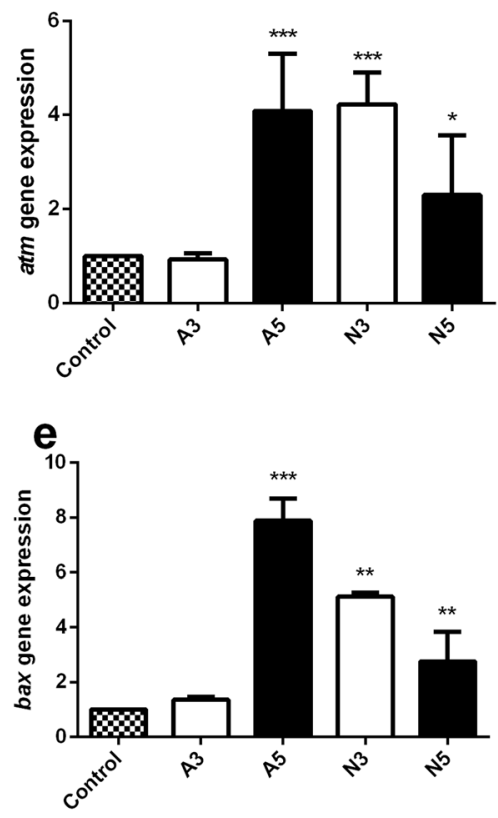

g

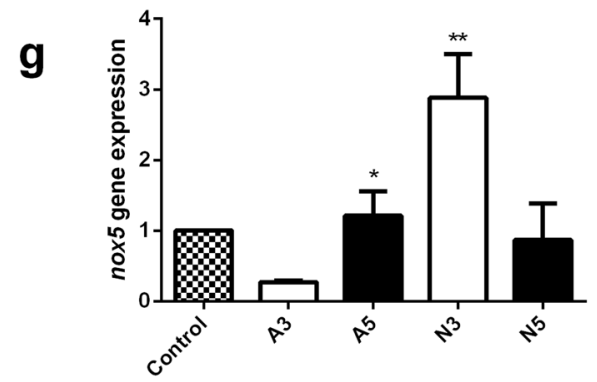

C
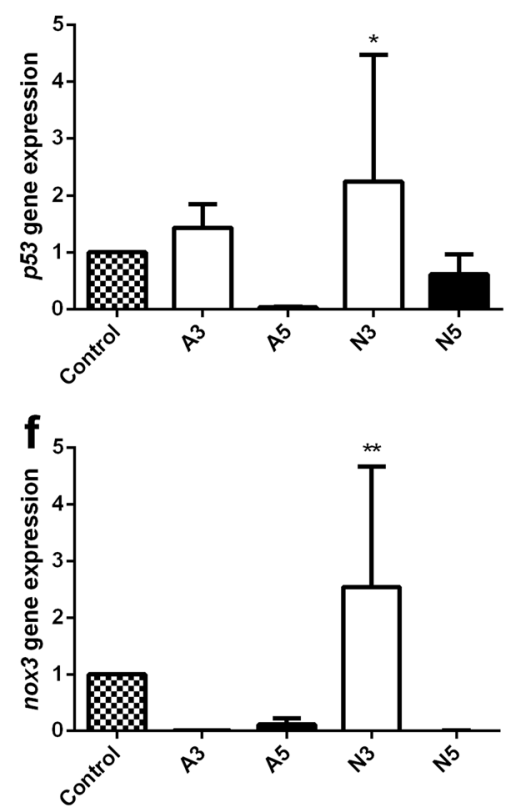

Figure 8. The relative value of mRNA expression of apoptosis and oxidative stress-related genes in SK-MEL-31 human melanoma cells after plasma exposure for $180 \mathrm{sec}(\mathrm{A} 3 / \mathrm{N} 3)$ and $300 \mathrm{sec}(\mathrm{A} 5 / \mathrm{N} 5)$ with air and $\mathrm{N}_{2}$ cold plasma. The relative mRNA expression of map38, atm, $p 53$, cas8, bax and nox (1-5) subfamily were measured by real-time RT-PCR and $18 s$ rRNA was used as a reference gene. Student's t-tests were performed, and the levels of significance are indicated as follows: ${ }^{*} \mathrm{p}<0.05 ; * \mathrm{p}<0.01$; and $* * * \mathrm{p}<0.001$.

be because of the interaction of CAP with liquid, which leads to various kinds of ROS in the culture media and linearly increases the level of intracellular $\operatorname{ROS}^{42,43}$. Because of the dependency of endogenous ROS generation on chemical induction, this direct ROS generation can be a good strategy for reducing melanoma. Previous reports stated that plasma induces cell death and reduced cell adhesion while interacting with organic components in cell culture media ${ }^{27,44}$, which leads to toxicity at later time intervals.

The cell death induced by soft jet plasma using $300 \mathrm{sec}$ air and $\mathrm{N}_{2}$ CAP showed apoptosis in the G-361, SK-MEL-31 and WM-266-4 melanoma cells which was apparent by the DAPI staining method. This can plausibly be explained by following two main processes: extrinsic and intrinsic pathways. Signalling from the death receptors plays a key role in mediating external signals to caspase8 in the extrinsic pathway. Also, CAP treatment generate $\mathrm{O}_{2}{ }^{--}$which on reaction with liquid cell culture medium may produce $\mathrm{HO}_{2}{ }^{\bullet}$ which is a strong oxidant than $\mathrm{O}_{2}{ }^{--}$and it can initiate lipid peroxidation of melanoma cells. $\mathrm{NO}_{2}{ }^{-}$is more unstable than $\mathrm{NO}_{3}{ }^{-}$and undergoes very fast decomposition which leads to $\mathrm{NO}_{2}{ }^{\bullet}$ and $\mathrm{OH}^{\bullet}$. These free radicals generation lead to another reason for apoptosis in melanoma.

In the molecular level, q-PCR analysis of the G-361 cells and WM-266-4 cells also revealed an increase in the casp 8 signal after $180 \mathrm{sec}(\mathrm{A} 3)$ of air CAP treatment and $300 \mathrm{sec}(\mathrm{N} 3)$ of $\mathrm{N}_{2}$ plasma treatment and this leads to the apoptosis. $b a x$ is a $b c l-2$ family gene that is related to the signaling of early apoptosis ${ }^{45}$. It was also reduced with A3 plasma treatment and N3 plasma treatment in the G-361 cells and A3 plasma treatment and N3 plasma treatment in the WM-2664 cells. However, SK-MEL-31 showed more necrosis compared to the other two melanoma cell lines. Plasma treatment of A3 showed $22.41 \%$ necrosis, while A5 treatment decreased the necrosis to $5.5 \%$. This was revealed by the casp 8 and bax activity at the same given CAP doses. Apart from the oxidative stress induced by RONS generated from air and $\mathrm{N}_{2}$ CAP, map38 was generally phosphorylated ${ }^{46}$. Upregulation of phospho 
a
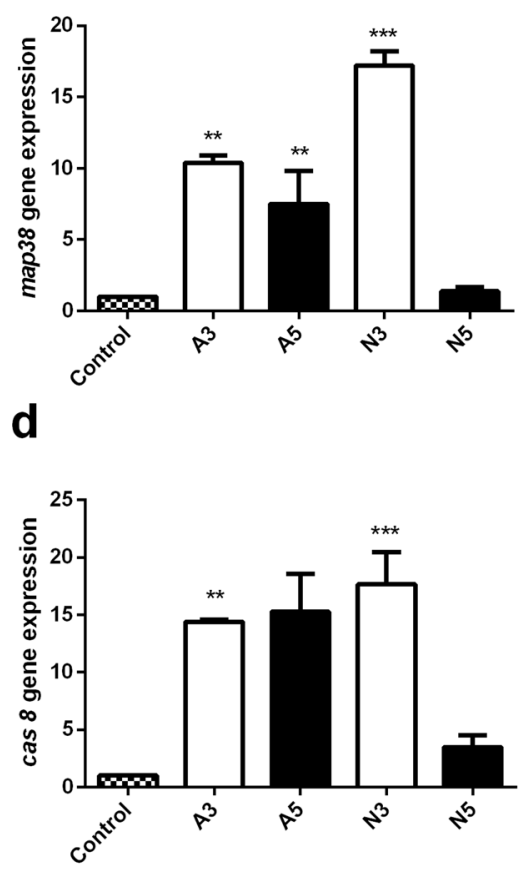

WM-266-4

b

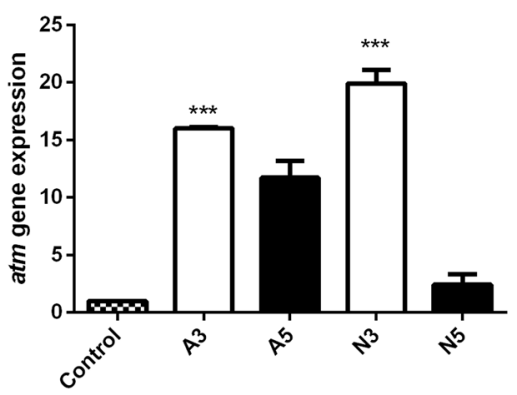

e

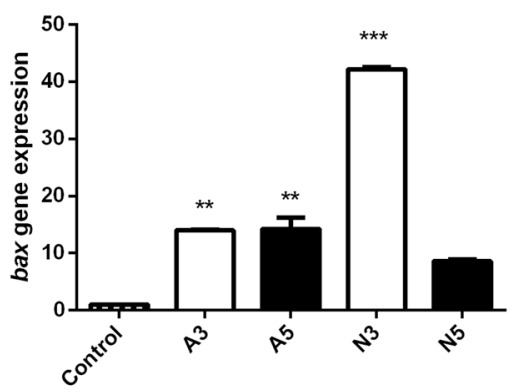

C
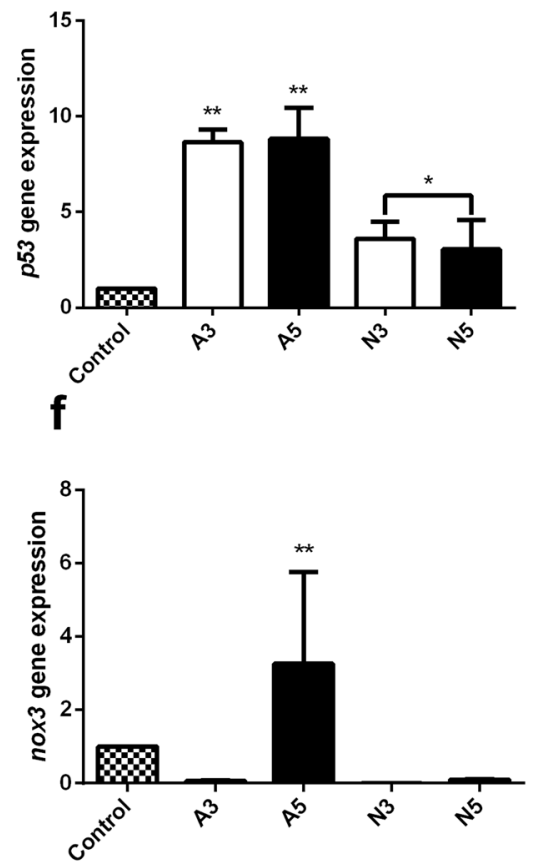

\section{g}

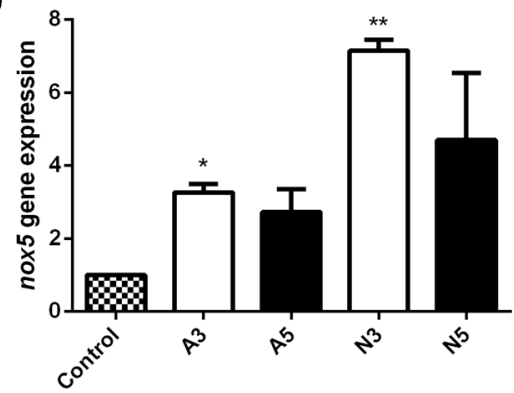

Figure 9. The relative value of mRNA expression of apoptosis and oxidative stress-related genes in WM-266-4 human melanoma cells after plasma exposure for $180 \mathrm{sec}(\mathrm{A} 3 / \mathrm{N} 3)$ and $300 \mathrm{sec}$ (A5/N5) with air and $\mathrm{N}_{2}$ cold plasma. The relative mRNA expression of map38, atm, $p 53$, cas8, bax and nox (1-5) subfamily were measured by real-time RT-PCR and $18 s$ rRNA was used as a reference gene. Student's t-tests were performed, and the levels of significance are indicated as follows: ${ }^{*} \mathrm{p}<0.05 ; * \mathrm{p}<0.01$; and $* * * \mathrm{p}<0.001$.

map38 signaling after A3 plasma treatment of G-361 and SK-MEL-31 and N3 CAP treatment of SK-MEL-31 and WM-2664 may upregulate apoptotic genes through distinct phosphorylation events. This can result in stress stimulating DNA damage ${ }^{46}$ and hence tumor cell death.

In our study, the softjet CAP using air and $\mathrm{N}_{2}$ ambient gases produced oxidative potential that was partially mediated through nox 1-5 enzymes and p53/atm overexpression. The gene overexpression in all three melanoma cell lines clearly indicates that RONS-dependent DNA damage triggered signaling leading to cell death. However, the actual damage to the different melanoma cells and the underlying mechanism must be studied to minimize the unexpected side effects of plasma medicine.

Based on the results of our experimental and computational study, we also propose the following mechanism for the ROS-regulated activation of $p 38$ pathways and subsequent signaling events that lead to apoptosis (Fig. 10). The activation of the primary $p 38$ pathway has been reported to lead to apoptosis and is induced by the activation of ASK $1^{47,48}$. In contrast, oxidative stress induced by RONS causes TRX to dissociate from ASK1, and the free ASK1 further activates $p 38$ pathways that lead to apoptosis ${ }^{49,50}$. The protein-protein interaction results for ASK1 and the TRX1-reduced form clearly showed that the catalytic residues Phe31, Cys32 and Cys35 of TRX1 oriented towards the Cys113 and Cys119 binding residues of ASK1. The calculated absolute energy score for this complex was $138,562.30 \mathrm{kcal} / \mathrm{mol}$. Similarly, the analysis of the complex of ASK1 and the TRX1-oxidised form showed a similar interaction with a decreased absolute energy score of 128,488.17 kcal/mol (Fig. S3). Our results corroborate earlier experimental studies showing that the activity of ASK1 is downregulated by the reduced TRX1 protein 


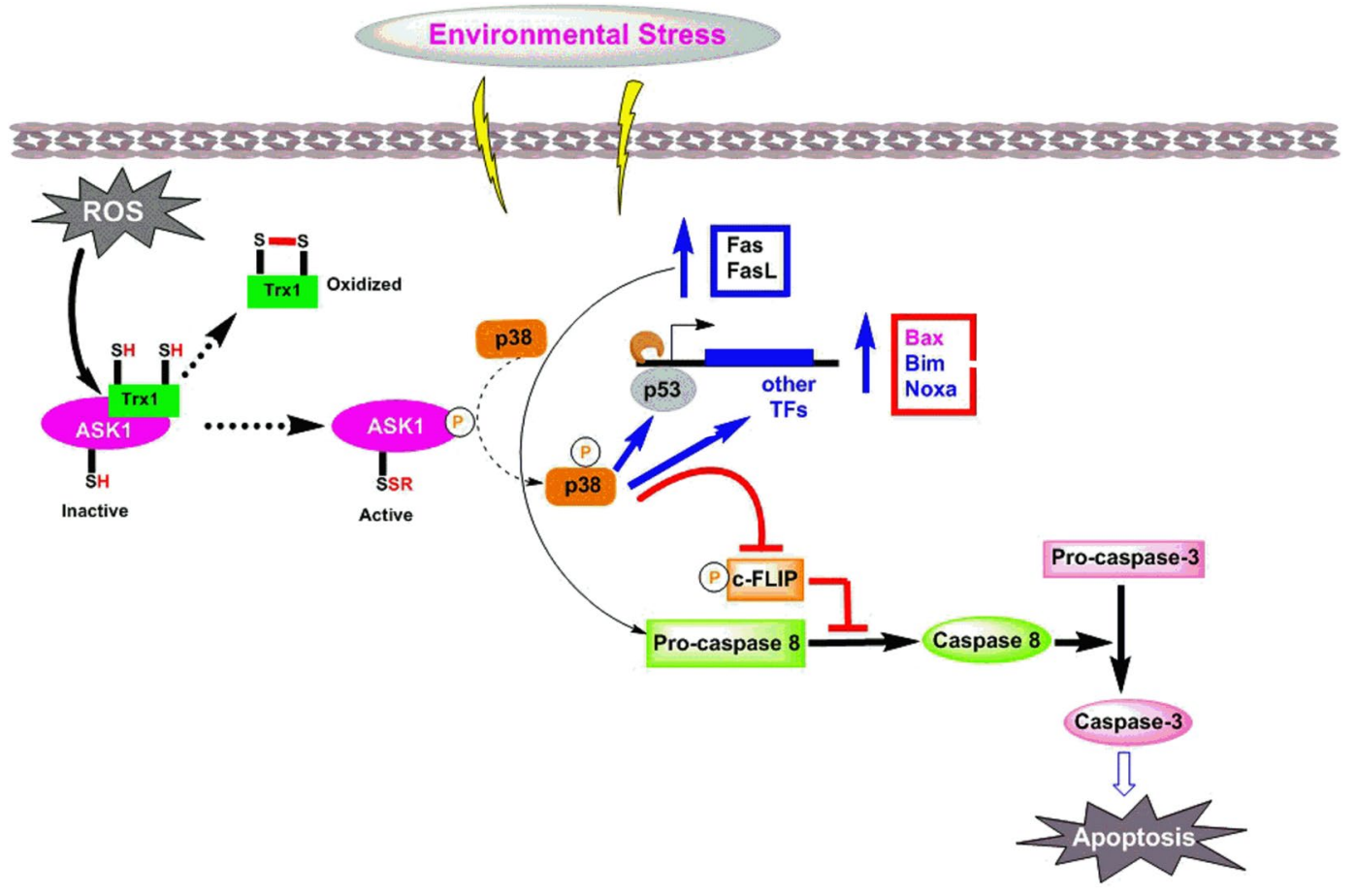

Figure 10. Illustrating the Reactive Oxygen and Nitrogen Species induced expression of the pro-apoptotic protein signaling cascade that leads to apoptosis.

and upregulated when the TRX1 protein is oxidized (i.e. disulfide bond Cys32-Cys35). In other words, ASK1 is in its free form to propagate $p 38$-mediated apoptosis ${ }^{48,51-59}$.

Oxidative stress with an increased concentration of RONS targets the ASK1:TRX1 protein complex and causes the release of TRX1 from ASK1 through the redox mechanism. The free ASK1 then phosphorylates p38 and activates the signaling cascade. The activated $p 38$ induces the expression of pro-apoptotic proteins such as Fas and its ligand (FasL), bax, bim, or nox-a (all from the $b c l-2$ family) through the phosphorylation of the transcription factor ( $p 53)$. Then, $p 38$ can inhibit c-FLIP phosphorylation and impair its function as an inhibitor of cas 8 activations. The expressed pro-apoptotic proteins Fas and FasL activate pro-cas 8 to cas 8 . This further activates cas 3 , which contributes to apoptosis.

In conclusion, the exact mechanism for the inhibitory effect of CAP remains unknown and needs to be further investigated. However, our results showed that air and $\mathrm{N}_{2}$ softjet CAPs are useful and powerful agents against human melanoma in vitro, where the main effects seem to be the activation of apoptosis and an increase in metabolic toxicity. For therapeutic applications, the different cellular responses to plasma treatment should be further screened according to cell morphology and cancer genotype and must be compared with the normal cells. However, our preliminary results show potential for the preferential killing of melanoma cells with softjet air and $\mathrm{N}_{2}$ CAP treatment in melanoma therapy.

Received: 8 July 2019; Accepted: 10 February 2020;

Published online: 25 February 2020

\section{References}

1. Clark, W. H., Tucker, M. A. \& Goldstein, A. M. Parenchymal-stromal interactions in neoplasia: theoretical considerations and observations in melanocytic neoplasia. Acta Oncologica 34, 749-757 (1995).

2. Jen, M., Murphy, M. \& Grant-Kels, J. M. Childhood melanoma. Clinics in dermatology 27, 529-536 (2009).

3. Kaddu, S., Smolle, J., Zenahlik, P., Hofmann-Wellenhof, R. \& Kerl, H. Melanoma with benign melanocytic naevus components: reappraisal of clinicopathological features and prognosis. Melanoma research 12, 271-278 (2002).

4. Weatherhead, S., Haniffa, M. \& Lawrence, C. Melanomas arising from naevi and de novo melanomas-does origin matter? British Journal of Dermatology 156, 72-76 (2007).

5. Yovino, J. \& Thaller, S. Potential for development of malignant melanoma with congenital melanocytic nevi. Journal of Craniofacial Surgery 16, 871-873 (2005).

6. Gilmore, S. Melanoma screening: Informing public health policy with quantitative modelling. PloS one 12, e0182349 (2017).

7. Curtin, J. A. et al. Distinct sets of genetic alterations in melanoma. New England Journal of Medicine 353, 2135-2147 (2005).

8. Winter, T. et al. Characterization of the global impact of low temperature gas plasma on vegetative microorganisms. Proteomics 11, 3518-3530 (2011).

9. Fridman, G. et al. Applied plasma medicine. Plasma Processes and Polymers 5, 503-533 (2008).

10. Daeschlein, G. et al. Antibacterial Activity of an Atmospheric Pressure Plasma Jet Against Relevant Wound Pathogens in vitro on a Simulated Wound Environment. Plasma Processes and Polymers 7, 224-230, https://doi.org/10.1002/ppap.200900059 (2010).

11. Ehlbeck, J. et al. Low temperature atmospheric pressure plasma sources for microbial decontamination. Journal of Physics D: Applied Physics 44, 013002 (2010). 
12. Fridman, G. et al. Blood coagulation and living tissue sterilization by floating-electrode dielectric barrier discharge in air. Plasma Chemistry and Plasma Processing 26, 425-442 (2006).

13. Shekhter, A. B., Serezhenkov, V. A., Rudenko, T. G., Pekshev, A. V. \& Vanin, A. F. Beneficial effect of gaseous nitric oxide on the healing of skin wounds. Nitric oxide 12, 210-219 (2005).

14. Isbary, G. et al. Cold atmospheric argon plasma treatment may accelerate wound healing in chronic wounds: Results of an open retrospective randomized controlled study in vivo. Clinical Plasma Medicine 1, 25-30 (2013).

15. Kim, C.-H. et al. Effects of atmospheric nonthermal plasma on invasion of colorectal cancer cells. Applied physics letters 96, 243701 (2010).

16. Cheng, X. et al. The effect of tuning cold plasma composition on glioblastoma cell viability. PloS one 9, e98652 (2014).

17. Kumar, N., Kaushik, N. K., Park, G., Choi, E. H. \& Uhm, H. S. Enhancement of glucose uptake in skeletal muscle L6 cells and insulin secretion in pancreatic hamster-insulinoma-transfected cells by application of non-thermal plasma jet. Applied Physics Letters 103, 203701 (2013).

18. Ghimire, B. et al. The effect of the gap distance between an atmospheric-pressure plasma jet nozzle and liquid surface on $\mathrm{OH}$ and $\mathrm{N} 2$ species concentrations. Physics of Plasmas 24, 073502, https://doi.org/10.1063/1.4989735 (2017).

19. Ghimire, B. et al. An atmospheric pressure plasma jet operated by injecting natural air. Applied Physics Letters 113, 194101, https:// doi.org/10.1063/1.5055592 (2018)

20. Ghimire, B. et al. The role of UV photolysis and molecular transport in the generation of reactive species in a tissue model with a cold atmospheric pressure plasma jet. Applied Physics Letters 114, 093701, https://doi.org/10.1063/1.5086522 (2019).

21. Kim, J. et al. Coagulation, deformability, and aggregation of RBCs and platelets following exposure to dielectric barrier discharge plasma with the use of different feeding gases. Journal of Physics D: Applied Physics 52, 155202, https://doi.org/10.1088/1361-6463/ ab0198 (2019).

22. Uhm, H. S. Generation of various radicals in nitrogen plasma and their behavior in media. Physics of Plasmas 22, 123506, https:// doi.org/10.1063/1.4936796 (2015).

23. Ahmed, S. A., Gogal, R. M. Jr. \& Walsh, J. E. A new rapid and simple non-radioactive assay to monitor and determine the proliferation of lymphocytes: an alternative to $[3 \mathrm{H}]$ thymidine incorporation assay. Journal of immunological methods 170, 211-224 (1994).

24. Mosmann, T. Rapid colorimetric assay for cellular growth and survival: application to proliferation and cytotoxicity assays. Journal of immunological methods 65, 55-63 (1983).

25. Kaushik, N. K., Kim, Y. H., Han, Y. G. \& Choi, E. H. Effect of jet plasma on T98G human brain cancer cells. Current Applied Physics 13, 176-180 (2013).

26. Ryu, Y.-H. et al. Effects of background fluid on the efficiency of inactivating yeast with non-thermal atmospheric pressure plasma. PLoS One 8, e66231 (2013).

27. Panngom, K., Baik, K. Y., Ryu, Y. H., Uhm, H. S. \& Choi, E. H. Differential responses of cancer cell lines to non-thermal plasma from dielectric barrier discharge. Current Applied Physics 13, S6-S11 (2013).

28. Bunkoczi, G. et al. Structural and functional characterization of the human protein kinase ASK1. Structure 15, 1215-1226 (2007).

29. Kylarova, S. et al. Cysteine residues mediate high-affinity binding of thioredoxin to ASK1. The FEBS journal 283, 3821-3838 (2016).

30. Kosek, D. et al. Biophysical and structural characterization of the thioredoxin-binding domain of protein kinase ASK1 and its interaction with reduced thioredoxin. Journal of Biological Chemistry, jbc. M114. 583807 (2014).

31. Weichsel, A., Gasdaska, J. R., Powis, G. \& Montfort, W. R. Crystal structures of reduced, oxidized, and mutated human thioredoxins: evidence for a regulatory homodimer. Structure 4, 735-751 (1996).

32. Schrödinger, L. Protein preparation wizard. Epik version 2 (2011).

33. Garzon, J. I. et al. FRODOCK: a new approach for fast rotational protein-protein docking. Bioinformatics 25, 2544-2551 (2009).

34. Ramírez-Aportela, E., López-Blanco, J. R. \& Chacón, P. FRODOCK 2.0: fast protein-protein docking server. Bioinformatics 32, 2386-2388 (2016)

35. Rello, S. et al. Morphological criteria to distinguish cell death induced by apoptotic and necrotic treatments. Apoptosis 10, 201-208 (2005).

36. Bedard, K. \& Krause, K.-H. The NOX family of ROS-generating NADPH oxidases: physiology and pathophysiology. Physiological reviews $87,245-313$ (2007).

37. Yamaura, M. et al. NADPH oxidase 4 contributes to transformation phenotype of melanoma cells by regulating G2-M cell cycle progression. Cancer research 69, 2647-2654 (2009).

38. Kang, J. et al. Functional interaction of H2AX, NBS1, and p53 in ATM-dependent DNA damage responses and tumor suppression. Molecular and cellular biology 25, 661-670 (2005).

39. Miller, N. \& Vile, R. Targeted vectors for gene therapy. The FASEB journal 9, 190-199 (1995).

40. Ahmann, D. L. et al. Complete responses and long-term survivals after systemic chemotherapy for patients with advanced malignant melanoma. Cancer 63, 224-227 (1989).

41. Yan, X. et al. Plasma-induced death of HepG2 cancer cells: intracellular effects of reactive species. Plasma Processes and Polymers 9 , 59-66 (2012).

42. Kalghatgi, S. et al. Effects of non-thermal plasma on mammalian cells. PloS one 6, e16270 (2011)

43. Joshi, S. G. et al. Non-thermal dielectric-barrier discharge (DBD) Plasma-induced inactivation involves oxidative-DNA damage and membrane lipid peroxidation in Escherichia coli. Antimicrobial agents and chemotherapy (2011).

44. Su, W.-P. et al. Mitochondrial uncoupling protein 2 regulates the effects of paclitaxel on Stat 3 activation and cellular survival in lung cancer cells. Carcinogenesis 33, 2065-2075 (2012).

45. Hoentsch, M., von Woedtke, T., Weltmann, K.-D. \& Nebe, J. B. Time-dependent effects of low-temperature atmospheric-pressure argon plasma on epithelial cell attachment, viability and tight junction formation in vitro. Journal of Physics D: Applied Physics $\mathbf{4 5}$, 025206 (2011).

46. Chen, W. et al. Cryptotanshinone activates p38/JNK and inhibits Erk1/2 leading to caspase-independent cell death in tumor cells. Cancer prevention research, canprevres. 0551.2011 (2012).

47. Corre, I., Paris, F. \& Huot, J. The p38 pathway, a major pleiotropic cascade that transduces stress and metastatic signals in endothelial cells. Oncotarget 8, $55684(2017)$.

48. Raninga, P. V., Di Trapani, G. \& Tonissen, K. F. Cross talk between two antioxidant systems, thioredoxin and DJ-1: consequences for cancer. Oncoscience 1, 95 (2014).

49. Saitoh, M. et al. Mammalian thioredoxin is a direct inhibitor of apoptosis signal-regulating kinase (ASK) 1. The EMBO journal 17, 2596-2606 (1998).

50. Liu, Y. \& Min, W. Thioredoxin promotes ASK1 ubiquitination and degradation to inhibit ASK1-mediated apoptosis in a redox activity-independent manner. Circulation research 90, 1259-1266 (2002).

51. Madan, E. et al. SCO2 induces p53-mediated apoptosis by Thr845 phosphorylation of ASK-1 and dissociation of ASK-1-TRX complex. Molecular and cellular biology, MCB. 06798-06711 (2013).

52. Liu, H., Nishitoh, H., Ichijo, H. \& Kyriakis, J. M. Activation of apoptosis signal-regulating kinase 1 (ASK1) by tumor necrosis factor receptor-associated factor 2 requires prior dissociation of the ASK1 inhibitor thioredoxin. Molecular and cellular biology 20, $2198-2208(2000)$. 
53. Kim, J. W. et al. Anti-cancer effect of GV1001 for prostate cancer; function as a ligand of GnRHR. Endocr. Relat. Cancer 26, 147-162 (2018).

54. Yadav, D. K. et al. Insight Into the Molecular Dynamic Simulation Studies of Reactive Oxygen Species in Native Skin Membrane. Frontiers in Pharmacology 9, 644 (2018).

55. Yadav, D. K. et al. Molecular Insights into the Interaction of RONS and Thieno[3,2-c]pyran Analogs with SIRT6/COX-2: A Molecular Dynamics Study. Scientific Reports 8, 4777 (2018).

56. Rai, R. et al. Synthesis, biological evaluation and molecular docking study of 1-amino-2-aroylnaphthalenes against prostate cancer. Bioorg. Med. Chem. Lett. 28, 1574-1580 (2018).

57. Yadav, D. K. et al. Studies of the benzopyran class of selective COX-2 inhibitors using 3D-QSAR and molecular docking. Arch. Pharm. Res. 41, 1178-1189 (2018).

58. Yadav, D. K. et al. New arylated benzo[h]quinolines induce anti-cancer activity by oxidative stress-mediated DNA damage. Scientific Reports 6, 38128 (2016).

59. Yadav, D. K. et al. Design, synthesis and in vitro evaluation of $18 \beta$-glycyrrhetinic Acid derivatives for anticancer activity against human breast cancer cell line MCF-7. Curr. Med. Chem. 21, 1160-70 (2014).

\section{Acknowledgements}

D.K.Y. is thankful to the Basic Science Research Program of the National Research Foundation of Korea (NRF) funded by the Ministry of Education, Science, and Technology, who supported this study (No. 2017R1C1B2003380). The authors are also thankful to the Gachon Institute of Pharmaceutical Science and Department of Pharmacy, College of Pharmacy, Gachon University of Medicine and Science of Incheon, Korea, for providing the computational modeling facilities. This research was also supported by the National Research Foundation of Korea (NRF) funded by the Korea government (MSIP) (NRF-2016K1A4A3914113).

\section{Author contributions}

D.K.Y. conceived and designed the project and collected data from the literature and databases. M.A., S.K., B.G., and D.K.Y. performed the experiments, analyzed the data, and wrote the manuscript. E.H.C. and M.H.K provided the lab facilities. All authors contributed to the interpretation and discussion of the results. All authors have read and approved the final version of the manuscript.

\section{Competing interests}

The authors declare no competing interests.

\section{Additional information}

Supplementary information is available for this paper at https://doi.org/10.1038/s41598-020-60356-0.

Correspondence and requests for materials should be addressed to D.K.Y. or E.-H.C.

Reprints and permissions information is available at www.nature.com/reprints.

Publisher's note Springer Nature remains neutral with regard to jurisdictional claims in published maps and institutional affiliations.

(c) (i) Open Access This article is licensed under a Creative Commons Attribution 4.0 International License, which permits use, sharing, adaptation, distribution and reproduction in any medium or format, as long as you give appropriate credit to the original author(s) and the source, provide a link to the Creative Commons license, and indicate if changes were made. The images or other third party material in this article are included in the article's Creative Commons license, unless indicated otherwise in a credit line to the material. If material is not included in the article's Creative Commons license and your intended use is not permitted by statutory regulation or exceeds the permitted use, you will need to obtain permission directly from the copyright holder. To view a copy of this license, visit http://creativecommons.org/licenses/by/4.0/.

(C) The Author(s) 2020 